\title{
Cloud Point Extraction of Pesticide Residues
}

\author{
Hayati Filik and Sema Demirci Çekiç \\ Istanbul University, Faculty of Engineering, Department of Chemistry, Istanbul
}

Turkey

\section{Introduction}

Pesticides including organochlorine pesticides (OCPs), organophosphorus pesticides (OPPs), and nitrogen-containing herbicides are types of well-known environmental contaminants. Pesticides are generally categorized based upon their persistence in the environment. Organochlorine pesticides are considered persistent pesticides. These pesticides have long environmental half-lives and tend to bioaccumulate in humans and other animals. The contemporary pesticides include organophosphates, carbamates, triazines, chloroacetanilides, synthetic pyrethroids, and others and are considered nonpersistent. These pesticides have much shorter environmental half-lives and tend not to bioaccumulate (Barr \& Needham, 2002). Table 1 provides a very abbreviated synopsis of major families, or chemical classes, of pesticides grouped by their uses. Among the pesticides, organophosphate and carbamate compounds are the most widely used due to their high insecticidal activity and relatively low persistence (Dyson et al., 2002). These pesticides are toxic because they act as inhibitors of acetylcholinesterase, an enzyme that catalysis in a very efficient way the hydrolysis of the neurotransmitter acetylcholine. This enzyme is present in vertebrates and insects and its inhibition can disrupt the transmission of nerve impulses (Hassal, 1983; Simonian et al., 1997). The increasing production and application of pesticides for agricultural and non-agricultural purposes has caused the pollution of air, soil, ground, and surface water which involves a serious risk to the environment and as well as human health due to either direct exposure or through residues in food and drinking water. In the world, alarming levels of pesticides have been reported in air, water, soil, as well as in foods and biological materials (Pico'et al., 2003; Lambropoulou \& Albanis, 2007; Guzzella et al., 2006; Konstantinou et al., 2006; Núñez et al., 2005; Harner et al., 2006; Chang \& Dong, 2006; Barr \& Needham, 2002). Nowadays, approximately 300000 tonnes of pesticides per year are used for agricultural production in Europe and their residues can be found in soil, water, foods, etc. For environmental and drinking waters, the maximum admissible concentration of a single compound established by the European Union (EU) is 0.1 , and $0.5 \mu \mathrm{g} \mathrm{L}^{-1}$ is the maximum allowed for the total concentration of all pesticides (http://ec.europa.eu/environment/water). The WHO threshold values for concentrations of pesticides in drinking water, based on toxicological considerations, are less strict than the maximum concentrations allowed by EU (Hamilton et al., 2003). Pesticide residues are highly mobile in soil and can leach into ground-water, so may be a potential health hazard. 


\begin{tabular}{|c|c|c|}
\hline Use: Family & Examples & Basic Structure \\
\hline \multicolumn{3}{|l|}{ Fungicides: } \\
\hline Dithiocarbamate & $\begin{array}{l}\text { mancozeb, maneb, } \\
\text { metiram, zineb }\end{array}$ & \\
\hline Imidazole & $\begin{array}{l}\text { carbendazim, } \\
\text { imazalil,thiabendazole }\end{array}$ & \\
\hline Phthalimide & $\begin{array}{l}\text { procymidone, } \\
\text { captan, captafol, folpet }\end{array}$ & \\
\hline Triazole & $\begin{array}{l}\text { myclobutanil, } \\
\text { propiconazole }\end{array}$ & \\
\hline \multicolumn{3}{|l|}{ Herbicides: } \\
\hline Acetamide & $\begin{array}{l}\text { alachlor, dichormid, } \\
\text { metolachlor }\end{array}$ & \\
\hline Chlorophenoxy & $\begin{array}{l}\text { 2,4-D, 2,4,5-T, } \\
\text { MCPA, silvex }\end{array}$ & \\
\hline Dinitroaniline & $\begin{array}{l}\text { pendimethalin, } \\
\text { trifluralin, dinitramine }\end{array}$ & \\
\hline Imidazolinone & $\begin{array}{l}\text { imazaquin, imazapyr, } \\
\text { imazethapyr }\end{array}$ & \\
\hline Phenylphenoxy & $\begin{array}{l}\text { fomesafen, bifenox, } \\
\text { fluazifop-butyl }\end{array}$ & \\
\hline Phenylurea & $\begin{array}{l}\text { linuron, diuron, } \\
\text { thidazuron, neburon }\end{array}$ & \\
\hline Sulfonylurea & $\begin{array}{l}\text { chlorsulfuron, } \\
\text { chlorimuron-ethyl }\end{array}$ & 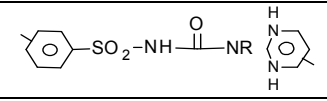 \\
\hline Thiocarbamate & $\begin{array}{l}\text { vernolate, asulam, } \\
\text { butylate, thiobencarb }\end{array}$ & \\
\hline Triazine & $\begin{array}{l}\text { amine, ametryn, } \\
\text { simazine, prometon }\end{array}$ & \\
\hline \multicolumn{3}{|l|}{ Insecticides: } \\
\hline Carbamate & $\begin{array}{l}\text { carbofuran, aldicarb, } \\
\text { propoxur, oxamyl }\end{array}$ & \\
\hline Organochlorine & $\begin{array}{l}\text { methoxychlor, DDE, } \\
\text { lindane, endosulfan }\end{array}$ & $\begin{array}{l}\text { insecticides containing } \\
\text { chlorine }\end{array}$ \\
\hline Organophosphorus & $\begin{array}{l}\text { diazinon, chlorpyrifos, } \\
\text { acephate, ethion }\end{array}$ & $\begin{array}{c}\mathrm{O}_{(\mathrm{I}}^{(\mathrm{S})} \\
\mathrm{H}-\mathrm{P}_{+}^{-} \\
\mathrm{I}\end{array}$ \\
\hline Pyrethroid & $\begin{array}{l}\text { permethrin, eyfluthrin, } \\
\text { fenvalerate, bifenthrin }\end{array}$ & \\
\hline
\end{tabular}

Table 1. Major types of pesticides (Lehotay, 1997). 
Since over 900 pesticid substances are used throughout the world, screening approaches are being developed to analyze as many pesticides as possible (Garcia-Reyes et al.,2008; Fernández-Alba, 2005).

The identification and determination of trace and ultra-trace pesticides in complex matrices still remains a challenge to analytical chemists. A number of spectrophotometric and flouorimetric methods have been developed in recent years for the determination of pesticides. The majority published spectrophotometric methods are based on coupling of a diazonium ion with the phenols obtained by hydrolysis of the carbamates in alkaline medium (Khalaf et al., 1993; Zanella et al.,1999; Alvarez-Rodríguez et al., 1997; Coly \& Aeron, 1998). Colorimetric and flouorimetric methods are sensitive, but not highly specific in general. The determination of pesticide residues is an intricate problem because of the large number of chemicals involved. The ideal method for the analysis of pesticide residues should have high sensitivity, selectivity, accuracy, high precision, and low cost and should be applicable to a wide range of sample matrices. Thus, several chromatographic techniques, such as high-performance liquid chromatography (HPLC), gas chromatography (GC), capillary electrophoresis (CE) and thin layer chromatography (TLC), can be applied for the determination of pesticides residues (Xie et al., 2010; Lambropoulou \& Albanis, 2007). Nowadays, hyphenated techniques such as gas chromatography-mass spectrometry (GCMS), liquid chromatography-mass spectrometry (LC-MS) is becoming popular and fast gaining grounds for pesticide residues analysis (Balinova \& Balinov, 1991; Bernal et al., 2009). Gas chromatography (GC) has been used widely for analysis of pesticide residues in plants tissues, soils and water samples (Yeboah et al., 2001; Roseboom \& Herbold, 1980; Balinova, 1996.). However, the thermal instability of some pesticides make them necessary to first prepare stable derivatives, and indirectly determine them by GC in the form of these derivatives, or to use other techniques such as liquid chromatographic (LC) or capillary electrophoresis (CE). Pesticide concentrations in real samples (water, food, etc.) are frequently very low and their direct determination is not possible; it is therefore necessary to perform previous pesticide enrichment and separation. Separation and preconcentration are areas of increasing interest, particularly for enhancing the inherent capabilities of analytical signals and lowering the detection limits in analytical chemistry. There are several different enrichment and pre-separation techniques for pesticides reported in literature, but each has its own limitations. Pesticide samples are usually enriched by liquid-liquid extraction (LLE), solid-phase extraction (SPE). LLE, based on the transfer of analyte from the aqueous sample to a water-immiscible solvent, is widely employed for sample preparation. The efficiency of this process depends on the affinity of analytes with the extracting solvent, ratio between the phases and number of extractions. Nevertheless, some shortcomings such as emulsion formation, use of large sample volumes and toxic organic solvents and hence, generation of large amounts of pollutants make LLE labour to be intensive, expensive, time-consuming and environmentally unfriendly. In addition, polar pesticides cannot be extracted sufficiently quantitative with nonpolar solvents. Another popular sample-preparation approach is solid-phase extraction (SPE). Although it uses much less solvent than LLE, the usage can still be considered significant, and normally an extra step of concentrating the extract down to a small volume is needed. SPE can be automated but this entails complexity and additional cost (Xu et al., 2007; Pena-Pereira et al., 2009; Rezaee et al., 2010).

The most frequently used methods for the extraction of organic compounds from soils are Soxhlet or ultrasonic extraction. Soxhlet extraction is the most widely used extraction method 
for organic pollutants strongly adsorbed in solid matrices. To extract soil samples with Soxhlet extractors takes a long time; the analyte is held at high temperature and temperature-sensitive pesticides may be destroyed. Moreover, large quantities of solvents are wasted and additional concentration and clean-up steps are necessary (Antunes et al., 2003; Luque de Castro \& García-Ayuso, 1998). Sonication is faster than Soxhlet extraction and allows extraction of large amounts of sample, but it still uses about as much solvent as the Soxhlet extraction (Ferrera et al., 2004). Chemical quantification in soil is particularly difficult since it is highly heterogeneous, and very efficient extraction methods are required. During the last years, several fast extraction techniques were developed to overcome the limitations of conventional methods. Pressurised liquid extraction (PLE), also named accelerated solvent extraction (ASE), microwave-assisted extraction (MAE), ultrasound-assisted extraction (UAE), supercritical fluid extraction (SFE) and subcritical water extraction (SWE) are techniques that can be used instead of Soxhlet for the extraction of organic compounds, because they are rapid compared to the several hours needed for Soxhlet extraction and, in turn, much less solvent is required (Ferrera et al., 2004 ; Tadeo et al., 2010; Xie et al., 2010, Eskilsson \& Mathiasson, 2000). Table 2 summarizes and compares the characteristics, advantages and disadvantages of each extraction technique (Xie et al., 2010; Carabias-Martínez et al., 2000c). Modern trends in analytical chemistry are towards the simplification and miniaturization of sample preparation procedures as they lead inherently to a minimum solvent and reagent consumption and drastic reduction of laboratory wastes. In view of this aspect, several micro-extraction techniques are being developed in order to reduce the analysis step, increase the sample throughput and to improve the quality and the sensitivity of analytical methods. Unconventional LLE methodologies have been arisen like: single drop microextraction (SDME), wetting film extraction (WFE), cloud point extraction (CPE), homogeneous liquidliquid extraction (HLLE), dispersive liquid-liquid microextraction (DLLME) and dispersive liquid-liquid microextraction based on solidification of a floating organic drop (DLLME-SFO) (Miro et al., 2005; Anthemidis \& Ioannou, 2009; Lambropoulou \&Albanis, 2007).

Because of the advantages mentioned below cloud point extraction has an increasing interest recent years. Separation and preconcentration based on cloud point extraction (CPE) are becoming an important and practical application of surfactants in analytical chemistry. The CPE has been used successfully for the pre-concentration of species of widely differing character and nature, such as metal ions, proteins and other biomaterials or organic compounds of strongly differing polarity. Historically, the first application of CPE for the extraction of metal ions forming complexes sparingly soluble in water was introduced by Watanabe \& Tanaka (1978). The technique is based on the property of most nonionic surfactants in aqueous solutions to form micelles and to separate into a surfactant-rich phase of a small volume and a diluted aqueous phase when heated to a temperature known as the cloud point temperature. The small volume of the surfactant-rich phase obtained with this methodology permits the design of extraction schemes that are simple, cheap, highly efficient, speedy, and of lower toxicity to the environment than those extractions that use organic solvents. CPE has been used to separate and preconcentrate pesticides as a step prior to their determination in hydrodynamic analytical systems such as liquid chromatography (LC), capillary electrophoresis (CE) and gas chromatography (GC). The theory and main findings of these procedures have been summarized in well-documented reviews (Paleologos et al., 2005; Madej, 2009; Silva et al., 2006; de Almeida Bezerra et al., 2005; Carabias-Martínez et al., 2000; Stalikas, 2002; Saitoh \& Hinze, 1991; Quina \& Hinze, 1999), there are no detailed reports on the applicability of the above-mentioned cloud point 
extraction techniques in pesticide analysis. The applications addressed in this review cover aqueous and solid environmental samples and food samples. Finally, possible future trends and developments of CPE in this area were briefly discussed.

\begin{tabular}{|c|c|c|c|c|}
\hline $\begin{array}{l}\text { Extraction } \\
\text { technique }\end{array}$ & $\begin{array}{l}\text { Solvent type } \\
\text { /Extraction } \\
\text { Time/Solvent } \\
\text { consumption }\end{array}$ & $\begin{array}{l}\text { Temperatur/ } \\
\text { Pressure/ } \\
\text { Cost }\end{array}$ & Disadvantages & Advantages \\
\hline Soxhlet & \begin{tabular}{|l|} 
Organic \\
solvent/ \\
$6-24 \mathrm{~h} /$ \\
$60-500 \mathrm{~mL}$ \\
\end{tabular} & $\begin{array}{l}\text { Boiling point } \\
\text { of Solvent/ } \\
\text { Atm.pressure/ } \\
\text { Low cost }\end{array}$ & $\begin{array}{l}\text { Long extraction time, } \\
\text { large consumption of } \\
\text { organic solvent, } \\
\text { exhaustive extraction, } \\
\text { preconcentration of } \\
\text { sample required after } \\
\text { extraction. }\end{array}$ & $\begin{array}{l}\text { Large amount of } \\
\text { sample, filtration not } \\
\text { required, not matrix } \\
\text { dependent, and easy } \\
\text { to operate }\end{array}$ \\
\hline $\begin{array}{l}\text { Supercritical } \\
\text { fluid } \\
\text { extraction } \\
(\mathrm{SFE})\end{array}$ & $\begin{array}{l}\mathrm{CO}_{2} / \\
30-60 \mathrm{~min} / \\
10-40 \mathrm{~mL}\end{array}$ & $\begin{array}{l}70-150^{\circ} \mathrm{C} / \\
15-50 \mathrm{MPa} / \\
\text { High cost }\end{array}$ & $\begin{array}{l}\text { Limited sample size, } \\
\text { extraction efficiency } \\
\text { depends on matrix } \\
\text { and analyte }\end{array}$ & $\begin{array}{l}\text { Fast extraction, non- } \\
\text { toxic, environmental } \\
\text { friendly, small amount } \\
\text { of solvent, filtration } \\
\text { not required, }\end{array}$ \\
\hline $\begin{array}{l}\text { Ultrasonic- } \\
\text { assisted } \\
\text { extraction } \\
\text { (UEA) }\end{array}$ & $\begin{array}{l}\text { Organic } \\
\text { solvent / } \\
30-60 \mathrm{~min} / \\
30-100 \mathrm{~mL}\end{array}$ & $\begin{array}{l}30-35^{\circ} \mathrm{C} / \\
\text { Atm. } \\
\text { pressure/ } \\
\text { Low cost }\end{array}$ & $\begin{array}{l}\text { Large amount of } \\
\text { organic solvent, labor } \\
\text { intensive, filtration } \\
\text { required, risk of } \\
\text { exposure to solvent } \\
\text { vapor. }\end{array}$ & $\begin{array}{l}\text { Fast method, large } \\
\text { amount of sample, not } \\
\text { matrix dependent, } \\
\text { easy to operate }\end{array}$ \\
\hline $\begin{array}{l}\text { Microwave- } \\
\text { assisted } \\
\text { extraction } \\
\text { (MAE) }\end{array}$ & $\begin{array}{l}\text { Organic } \\
\text { solvent / } \\
20-30 \mathrm{~min} / \\
10-40 \mathrm{~mL}\end{array}$ & $\begin{array}{l}100-150 \text { 0 C / } \\
\text { Atm. } \\
\text { Pressure/ } \\
\text { Moderate cost }\end{array}$ & $\begin{array}{l}\text { Extracts must be } \\
\text { filtered, polar solvent } \\
\text { needed, exhaustive } \\
\text { extraction, }\end{array}$ & $\begin{array}{l}\text { Fast extraction, small } \\
\text { amount of solvent, and } \\
\text { full control of } \\
\text { extraction parameters }\end{array}$ \\
\hline $\begin{array}{l}\text { Pressurized } \\
\text { liquid } \\
\text { extraction } \\
(\mathrm{PLE})\end{array}$ & \begin{tabular}{|l|} 
Organic \\
solvent / \\
$10-60 \mathrm{~min} /$ \\
$10-60 \mathrm{~mL}$ \\
\end{tabular} & $\begin{array}{l}\text { 100-150 }{ }^{0} \mathrm{C} / \\
7-15 \mathrm{MPa} / \\
\text { High cost }\end{array}$ & $\begin{array}{l}\text { Extraction efficiency } \\
\text { is more matrix } \\
\text { dependent }\end{array}$ & $\begin{array}{l}\text { Fast technique, small } \\
\text { solvent usage, no } \\
\text { filtration needed and } \\
\text { easy to use. }\end{array}$ \\
\hline $\begin{array}{l}\text { Subcritical } \\
\text { water } \\
\text { extraction } \\
\text { (SWE) }\end{array}$ & $\begin{array}{l}\text { Water/ } \\
30-60 \mathrm{~min} / \\
30-60 \mathrm{~mL}\end{array}$ & $\begin{array}{l}200-300^{\circ} \mathrm{C} / \\
5 \mathrm{MPa} / \\
\text { Moderate cost }\end{array}$ & $\begin{array}{l}\text { Required } \\
\text { optimization of } \\
\text { operating conditions }\end{array}$ & $\begin{array}{l}\text { Fast method, water is } \\
\text { non-toxic, } \\
\text { environmental } \\
\text { friendly, small amount } \\
\text { of solvent. }\end{array}$ \\
\hline $\begin{array}{l}\text { cloud point } \\
\text { extraction } \\
(\mathrm{CPE})\end{array}$ & \begin{tabular}{|l|} 
Surfactant \\
solution /10- \\
20 min / \\
$5-10 \mathrm{~mL} \mathrm{CP}$ \\
of surfactant \\
\end{tabular} & $\begin{array}{l}\text { Atm. } \\
\text { Pressure/ } \\
\text { Low cost }\end{array}$ & $\begin{array}{l}\text { Required } \\
\text { optimization of } \\
\text { operating conditions }\end{array}$ & $\begin{array}{l}\text { Fast extraction, } \\
\text { surfactant is non-toxic, } \\
\text { environmental } \\
\text { friendly, small amount } \\
\text { of solvent. }\end{array}$ \\
\hline
\end{tabular}

Table 2. Comparison of various extraction techniques for pesticides in solid samples (Xie et al., 2010; Carabias-Martínez et al., 2000c). 


\section{Principle of cloud-point extraction (CPE)}

The extraction method using surfactants, termed "cloud point extraction or micellemediated extraction" provides an alternative to the conventional extraction systems due to its easy steps and lack of requirement for organic solvents. CPE is a new promising environmentally benign extraction technique which is based upon phase separation behavior exhibited by aqueous solutions of certain surfactant micelles. Surfactants are amphiphilic organic substances. Their molecules present a long hydrophobic hydrocarbon chain and a small charged group or polar hydrophilic. The combination of hydrophilic and hydrophobic groups in the same molecule provides to the surfactant a property of dissolution in water and others solvents. The hydrophobic groups tend to form aggregates called micelles. The concentration at which surfactants begin to form micelle is known as the critical micelle concentration (CMC). The CMC of a surfactant depends on several factors, such as its molecular structure, and experimental conditions such as ionic strength, counterions, temperature, etc. Upon appropriate alteration of the conditions such as temperature or pressure, addition of salt or other additives, the solution becomes turbid at a temperature known as cloud point $(\mathrm{CP})$ due to the diminished solubility of the surfactant in water. CP varies widely with temperature from one surfactant to another. When the temperature reaches the cloud point, the solution containing the surfactant becomes turbid and is separated into two phases: the small volume "surfactant-rich phase" and the large volume of "aqueous phase". This phenomenon is reversible and upon cooling, a single isotropic phase is obtained again. However, the mechanism by which separation occurs is poorly understood. Some authors have proposed that it would be due to an increase in the micellar aggregation number when temperature is increased (Lindman \& Wennerstrom, 1991; Corti et al., 1984). And some others have suggested that the phase separation at the lower consolution point is driven by the effective inter-micellar interaction potential which is repulsive at low temperature but becomes attractive at high temperature (DeGiorgio et al., 1984). Other authors have proposed that the phase separation behavior is a result of the competition between the internal-energy effects which promote separation of micelles from water and entropic effects together with the miscibility of micelles in water (Blankschtein et al., 1986; Liu et al., 1996). Kjellander \& Florin (1981) and Claesson et al. (1986) have also proposed that the phase separation results from the competition between entropies (Shariati \& Yamini., 2006)

In aqueous solution, the unique structure of surfactant allows sparingly soluble or waterinsoluble substances to be solubilized because they can associate and bind to the micellar assembly (Quina \& Hinze, 1999). Aqueous solutions of some surfactants have been used in CPE of different species prior to their determination by several techniques (Paleologos et al., 2005; Silva et al., 2006; de Almeida Bezerra et al., 2005; Madej, 2009; Stalikas, 2002). The interaction between surfactant and analyte may be electrostatic, hydrophobic or a combination of both (Ferrera et al., 2004). CPE mainly depends on the solubilization of surfactant solution and phase separation for the extraction and preconcentration of analytes (Pramauro \& Prevot, 1995). The use of micellar systems as an alternative to other techniques of separation offers several advantages including low cost, safety and high capacity to concentrate a wide variety of analytes of widely varying nature with high recoveries and very high concentration factors. The extraction efficiency for the target analyte by CPE is influenced by many factors, such as $\mathrm{pH}$ of a sample solution, surfactant type and concentration, temperature and duration of reaching equilibrium and ionic strength. The 
effect of these factors on the percentage extraction of the analytes studied therefore needs to be established. The steps of the cloud point extraction process are shown in Fig. 1 .

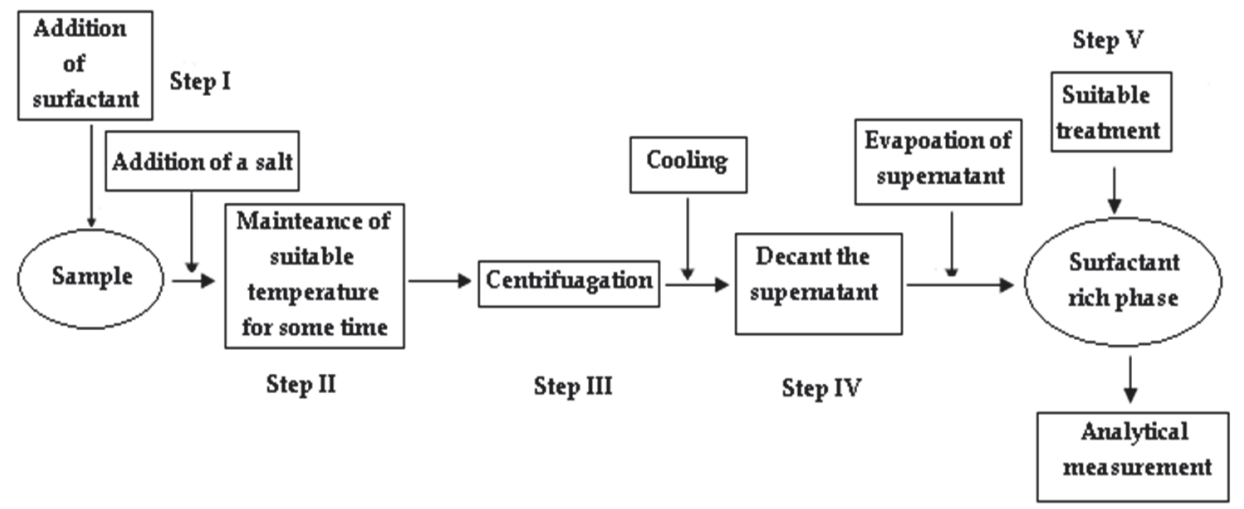

Fig. 1. Five key steps in cloud-point extraction (CPE) (Madej, 2009).

\subsection{Effect of $\mathrm{pH}$}

The $\mathrm{pH}$ effect on CPE depends on the characteristics of both surfactants and analytes. Solution $\mathrm{pH}$ is an important factor during CPE process involving analytes that possess an acidic or basic moiety. For organic molecules, especially for ionizable species, maximum extraction efficiency is achieved at $\mathrm{pH}$ values where the uncharged form of the analyte prevails, and therefore, target analyte is favored to be partitioned into the micellar phase. The ionic form of a neutral molecule formed upon deprotonation of a weak acid or protonation of a weak base normally does not interact with and bind the micellar aggregate as strongly as its neutral form does. However, changing the $\mathrm{pH}$ will change the ionization form of certain analytes and will thereby affect their water solubility and extractability. Thus, $\mathrm{pH}$ appears to be also an important factor for the cloud point extraction of pesticides from water samples. Generally, the relationship between $\mathrm{pH}$ and extraction efficiency has not been studied extensively, and contradictory results have been reported (Zhang et al., 2009). In most of the CPE studies in pesticide analysis, the $\mathrm{pH}$ of the samples is not adjusted. Furthermore, a wide range of $\mathrm{pH}$ values between 2 and 10 has been reported for the analysis of organochlorine and organophosphorus pesticides (de Almeida Bezerra et al, 2005; Madej, 2009; Xie et al., 2010).

\subsection{Properties of surfactant}

Surfactants are amphiphilic organic substances. Their molecules present a long hydrophobic hydrocarbon chain and a small charged group or polar hydrophilic. A typical surfactant has a $\mathrm{R}-\mathrm{X}$ structure, where $\mathrm{R}$ is a hydrocarbon chain, which can have between 8 and 18 atoms of carbon, and $X$ is the polar or ionic head group. The most usual chemical classification of surfactant is based on the hydrophilic group nature. A surfactant can be classified by the presence of formally charged groups in its head. The four general groups of surfactants are defined as non-ionic, cationic, anionic, and amphoteric (or zwitterionic) (de Almeida Bezerra et al., 2005). A non-ionic surfactant has no charge groups in its head. The head of an ionic surfactant carries a net charge. If the charge is negative, the surfactant is more specifically 
called anionic; if the charge is positive, it is called cationic. If a surfactant contains a head with two oppositely charged groups, it is termed zwitterionic. However, the application of cationic surfactants in CPE is scarce. A correct choice of surfactant is fundamental for obtaining an optimal extraction process. When selecting the extractant, consideration should be given to its interaction with the matrix, as well as the solubility of the analyte. To date, non-ionic surfactants (mainly polyoxyethylenated alkylphenols, from the Triton series, Igepal series and PONPE series) are those most widely employed for CPE pesticide analysis. They are all commercially available of high purity grade, stable, non-volatile, non-toxic and environmentally friendly. The extraction efficiency typically increases with a surfactant concentration up to a maximum value, with essentially quantitative recovery often being observed. Thus, the minimum concentration that produces quantitative extraction should be chosen in order to obtain the best aqueous phase volume/surfactant-rich phase volume ratio. As a general principle, CPE will be more efficient when more hydrophobic surfactants and more hydrophobic analytes are used (Paleologos et al., 2005; Silva et al., 2006; de Almeida Bezerra et al., 2005; Madej, 2009; Stalikas, 2002).

\subsection{Effect of concentration}

It is important to discuss the effect of surfactant concentration on CPE. The surfactant concentration affects both the extraction and theoretical preconcentration factor. During $\mathrm{CPE}$, the recoveries and theoretical maximum enrichment depended mainly upon the concentration of surfactant. Thus, it is necessary to optimize the surfactant concentration for sufficient extraction of the target analytes. There is a narrow range within easy phase separation, maximum extraction efficiency and accomplished analytical signal. Increasingly, outside this optimal range, the analytical signal is observed to deteriorate due to the increase in the final volume of the surfactant that causes the preconcentration factor (phase-volume ratio) to decrease. However, if surfactant concentration is decreased from that recommended, accuracy and reproducibility would probably suffer because the resultant surfactant-rich phase would not be sufficient to make reproducible measurements of extraction and separation. The surfactants, which have too high or too low cloud point, are not suitable for the CPE separation/preconcentration of trace pesticide residues.

\section{4 lonic strenght}

The cloud point of micellar solutions can be altered by salt addition, presence of alcohol, other surfactants, polymers, and some organic or inorganic compounds, which can cause an increase or decrease on the phase micellar solubility (de Almeida Bezerra et al., 2005). It was observed that the presence of electrolytes decreases the cloud point (salting-out effect), resulting in low extraction efficiency. The salt concentration is also a key parameter in CPE. The addition of inert salt to the solution can influence the extraction/preconcentration process since it can alter the density of the aqueous phase for most non-ionic surfactants and remarkably facilitate phase separation. Also, it can change the $\mathrm{CP}$ temperature of non-ionic surfactant (Saitoh \& Hinze, 1991; Hinze et. al. 1984). When the salt concentration is increased, the micelle size and the aggregation number are increased and the critical micellar concentration remains constant (Fröschl et al.,1997). The recovery increases with the inert salt concentration up to saturation. In addition, non-polar analytes may become less soluble in the solution at higher salt concentrations and thus contribute to higher recoveries. The results obtained indicate that the addition of salt produces an increase in the extraction 
of the more polar solutes while the recoveries of the less polar compounds are not affected (Carabias-Martinez et al., 2000; Eiguren-Fernández et al., 1998, 1999). According to Komaromy-Hiller et al. (1996) the salting-out phenomenon is directly related to desorption of ions to the hydrophilic parts of the micelles, increasing interaction between micelles and consequently leading to the precipitation of surfactant molecules.

\subsection{Effect of equilibration temperature and time}

The cloud-point temperature depends on the structure of the surfactant and on its concentration. Thus, optimal equilibration temperature and incubation time are necessary to complete reactions, and to achieve easy phase separation and preconcentration as efficient as possible. If the temperature is lower than the cloud-point, two phases cannot be formed. But too high temperature may lead to the decomposition of analytes. The greatest analyte preconcentration factor is reached when the CPE process is conducted with equilibration temperatures well above the cloud point temperature of the system. Moreover, by increasing the equilibration temperature, a reduction in the surfactant rich phase has been observed (Okada, 1992). Thereby, the preconcentration factor increases with increasing temperature depending on the surfactant concentration. As the temperature, or the equilibration time, increases, the amount of water in a surfactant-rich phase decreases and hence the volume of that phase decreases. Optimal equilibration temperature surfactant is important, since the temperature corresponding to cloud point is correlated with the hydrophilic property of surfactants.

\subsection{Effect of of centrifugation}

In general, centrifugation time hardly ever affects micelle formation but accelerates phase separation in the same sense as in conventional separations of a precipitate from its original aqueous environment. Centrifugation times around 5-10 min are usually efficient for most micelle-mediated extraction (MME) procedures. If the temperature is lower than the cloud point, the phase separation is difficult to be formed (Paleologos et al., 2005)

\section{Analytical applications}

The identification and determination of very low levels of pesticides in complex matrices is extremely difficult. Recently a promising environmentally benign extraction and preconcentration methodology based on cloud point extraction (CPE) has emerged as an efficient sample pretreatment technique for the determination of trace/ultra-trace pesticides in complex matrices. Here we address the most recent analytical applications of this methodology when used as an isolation and trace enrichment step prior to the analysis of pesticides via spectrophotometry, liquid and gas chromatography or capillary electrophoresis. Table 3 summarizes some recent applications in this topic along with fundamental features of the methods developed.

\subsection{Spectrophotometry}

A procedure for $\mathrm{CPE}$ and spectrophotometric determination of carbaryl in natural waters is described for the first time by Melchert \& Rocha (2009). Carbaryl is hydrolysed in alkaline medium to 1-naphthol, which reacts with the oxidised form of $p$-aminophenol (PAP), generated by reaction with molecular oxygen or other oxidising agent. Addition of oxidising 
agents is usually required to convert PAP to benzoquinoneimine that reacts with 1naphthol. After extraction of the reaction product with a nonionic surfactant, the indophenol blue species in the surfactant-rich phase is measured by spectrophotometry at $\lambda=630 \mathrm{~nm}$. The clean up step was carried out only with TX-114 in alkaline medium in order to avoid the use of toxic organic solvents as well as to minimise waste generation. Cloud point preconcentration of the product of the reaction of the analyte with PAP and cetyltrimethylammonium bromide $(\mathrm{CTAB})$ was explored to increase sensitivity and improve the detection limit.

Extraction of analytes from sample matrices is a challenging task. Non-ionic surfactants such as TX-100 and TX-114, have been widely used as extractant for various organic compounds. However, high temperature $\left(>70{ }^{\circ} \mathrm{C}\right)$ is required for $\mathrm{CPE}$, so it may affect on the stability of the compounds especially carbamate insecticides. Acid-induced anionic surfactant micellemediated extraction (acid-induced $\mathrm{CPE}$ ) has been demonstrated to be a powerful method for the extraction of carbaryl residues in water and vegetable matrices prior to spectrophotometric detection. An acid-induced CPE is employed for extraction of thermallylabile carbaryl. In acid-induced CPE, anionic surfactants such as sodium dodecyl sulfate, sodium dodecyl sulfonate and sodium decyl sulfate are used as extractants. The main advantages of this approach are the absence of UV chromophores in alkylsulfate or alkylsulfonate molecules, the lack of time and temperature dependence in the extraction step, the speed of extraction and the ability to extract thermally labile and polar compounds. Santalad et al. (2008) demonstrated a method for the determination of carbaryl based on acid-induced anionic surfactant micelle-mediated extraction (acid-induced-CPE) coupled to derivatization with 2-naphthylamine-1-sulfonic acid (ANSA) reagent. In this method, an anionic surfactant, sodium dodecyl sulfate (SDoS) and concentrated $\mathrm{HCl}$ were used as extractants at room temperature. ANSA derivatization was directly reacted with carbaryl without alkali hydrolysis. The conditions for both extraction and derivatization are optimized before applying to spectrophotometric determination of carbaryl residues in waters and vegetables. The proposed method shows good analytical features with low detection limit $\left(50 \mu \mathrm{g} \mathrm{L}^{-1}\right)$ as well as linearity covered a wide range up to $7.0 \mathrm{mg} \mathrm{L}^{-1}$, good precision with the RSD of $2.3 \%$, and high recoveries in the samples (> 85\%).
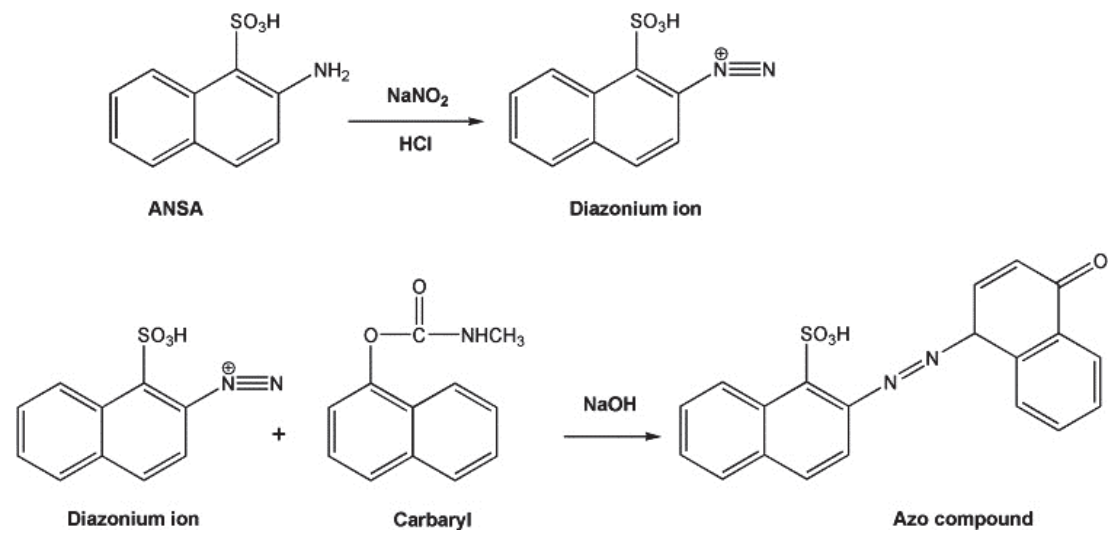

Fig. 2. Proposed reaction mechanism of carbaryl with 2-naphthylamine-1-sulfonic acid by means of diazotization reaction (Santalad et al. , 2008). 
Stangl \& Niessner (1994) presented a CPE-spectrofluorimetric method for determination of the herbicide napropamide and thiabendazole in water and soil samples. The analytes could be quantitatively extracted to the phase rich in the surfactant Genopol X-080 and be concentrated, then determined by spectrofluorimetry. The detection of thiabendazole and napropamide were performed by excitation at $297 \mathrm{~nm}$ and $290 \mathrm{~nm}$, respectively. The use of Genapol X-080 and Genapol 150 combined with fluorimetric detection has been applied (Stangl et al. 1995). The results obtained in this study indicate that the use of Genapol X-080 provides better results than Genapol 150 for the extraction-preconcentration of the herbicide napropamide using CPE methodology. Genapol X-080 should be prefered due to a shorter extraction time. One advantageous feature of micellar systems (CPE) is the enhanced fluorescence sensitivity due to diminished quenching.

\subsection{High-performance liquid chromatography}

The CPE technique has been successfully exploited for the extraction/preconcentration of pesticides as a sample pretreatment step using a variety of non-ionic surfactants, such as TX 114 prior to their determination by HPLC (Carabias-Martínez et al., 1996; Zhou et al., 2009 a, b), TX-100 (Zhang et al., 2009, 2011; Chen et al., 2009), polyoxyethylene 10 lauryl ether (POLE) (Sanz et al., 2004), oligoethylene glycol monoalkyl ether (Genapol X-080) (Sanz et al., 2004), polyethylene glycol 600 monooleate (PEG600MO) (Tang et al., 2010). A general problem encountered by both zwitterionic and non-ionic surfactants in CPE is that the surfactant-rich phase is too viscous for convenient sampling by a HPLC micro-syringe. Thus, in some applications, a relatively small volume of an appropriate solvent (diluent) has been added to dilute the surfactant-rich phase (Saitoh \& Hinze 1991). When cloud point extraction prior to HPLC analysis is used, two important disadvantages arise: a high background absorbance at UV detection and the lengthy operating time required for total elution of the surfactant injected. These two drawbacks clearly affect the use of this methodology in chromatographic determinations with optical detection (Pinto et al., 1992). The surfactant-rich phase obtained in the extraction process is compatible with the hydroorganic phase which is usually employed in HPLC. However, one of the greatest limitations to this methodology is the high absorbance shown by many surfactants in the UV region; in most cases, this prevents their use in a step prior to chromatographic separation when a system of spectrophotometric detection is to be used later unless the mobile phase used contains a high methanol content, in which case elution of the surfactant occurs in a short period of time and does not hinder detection of the analyte (Pinto et. al., 1995). Several ways to overcome this problem have been proposed: Saitoh \& Hinze (1991) used the zwitterionic surfactants 3-(nonyldimethylammonium) propyl sulfate $\left(\mathrm{C}_{9} \mathrm{APSO}_{4}\right)$ and 3-(decyldimethylammonium) propyl sulfate $\left(\mathrm{C}_{10} \mathrm{APSO}_{4}\right)$ which do not absorb at the customary working wavelengths in HPLC, Pinto et al., (1992) and Moreno-Cordero et al. (1993) used electrochemical detection owing to the electrodic inactivity of commercially available surfactants such as TX-114, and Ferrer et al. (1996) used a clean-up step with a silica gel column to remove the surfactant before sample injection. When injecting the surfactant-rich phase (neat or diluted) into a HPLC system, it is often necessary to wash the nonionic surfactant from the analytical column with a strong hydroorganic mobile phase between the chromatographic runs (Quina \& Hinze, 1999).

A soil washing/CPE technique has been used for the decontamination of soil polluted with DDT. Evdokimov \& von Wandruszka (1998) proposed a mixture of two surfactants-Igepal 
CO-630 (ICO-630) and TX-114 -for studying the possible elimination of DDT from polluted soils; the recovery percentage obtained proved to be greater than $83 \%$ when polluted soil in question was treated for $2 \mathrm{~h}$ with a $3 \%$ mixture of the surfactants. Soil samples spiked with DDT were washed with $3 \%$ and $5 \%$ nonionic surfactant solutions consisting of a mixture of ICO-630 and TX-114. The extraction of DDT from the soil matrix was monitored by HPLC of the washing solution.

Recently the use of microwave-assisted extraction (MAE) technique in the CPE process has been developed. Microwave-assisted extraction (MAE) has became a viable alternative to the conventional techniques. It has been reported that the combination of MA with micellar media as extractants (microwave-assisted cloud point extraction) (MA-CPE) allows the extraction of different organic compounds from solid samples (Ferrera et al., 2004). In conventional extraction techniques, a higher volume of solvent will generally increase the recovery, but, in MA-CPE, a higher surfactant volume does not influence the extraction efficiency. MA-CPE in combination with HPLC for the determination of organochlorine pesticides (OCPs) has also been reported (Moreno et al., 2006). OCPs such as DDT, dieldrin and aldrin have been determined in agricultural soils by MA-CPE with two non-ionic surfactant mixtures (POLE/polyoxyethylene 10 cetyl ether and POLE/polyoxyethylene 10 stearyl ether) prior to their separation by HPLC with UV detection. An experimental design was applied for the determination of variables which affect to recovery and to optimize the extraction parameters, surfactant concentration and volume, microwave time and power. The optimized method was used to determine the extraction of the pesticides from five different types of agricultural soils spiked with the mixture of OCPs. The recoveries largely depend on the type of surfactant mixture used and soil characteristics. The soils with high organic matter have good recoveries because the surfactant can also extract humic substances which are linked to the pesticides. But these recoveries decreases when the temperature is too high. On the other hand, the recoveries decrease with the aging time for all compounds which could be explained for the sorption process. The former phenomenon occurs at the early stages of sorption, where H-bonding and Van der Waals forces prevail. Only in the case of dieldrin using Stearyl mixture, the recovery remains practically constant with the time.

Carbamate pesticides are polar compounds and can be extracted with the CPE method. However, they cannot be directly determined with the CPE-HPLC-UV method due to the intense absorption of surfactant in the UV region. This problem can be possibly solved by using surfactants that do not absorb at the working wavelengths used in chromatography (Saítoh \& Hinze, 1991) or employing cleanup procedures (Carabías-Martínez et al., 2000). However, these methods are somewhat inconvenient. Zhou et al. (2009b) proposed another simple way to overcome this drawback. This method is to make the working wavelength red shift, which is based on the formation of colored products derived from the pesticides. The method is applied to determine the four pesticides (Arprocarb (AC), carbofuran (CF), isoprocarb (IC), and fenobucarb (FC) ) in corn samples. First the pesticides are hydrolyzed into different phenols in alkaline solution. The resultant hydrolysis products (i.e.,phenols) are reacted with 4-aminoantipyrene (AP) to form intensely red colored compounds in the presence of an alkaline oxidizing agent. The colored compounds are enriched and separated by CPE method, and the coacervate phase containing the compounds is determined with a HPLC system in the visible region. The CPE-HPLC-Vis method has been shown to be very attractive for the detection of carbamate pesticides. Compared with the absorbance maximum of the four carbamate pesticides $(\lambda=230 \mathrm{~nm})$, the wavelength positions of 
derivants are in the visible region $(\lambda=510 \mathrm{~nm})$. In this case, the background absorbance of TX-100 does not overlap with the peak of targets. Therefore, the surfactant-rich phase was directly analyzed with the HPLC system in the visible region. The derivatization method could also increase the detectability of carbamate detection in HPLC analysis.

Prometryne [2,4-bis(isopropylamino)-6-(methylthio)-s-triazine], a selective herbicide of the s-triazine chemical family, has been extensively used as a pre- or post-emergence controller of annual grasses and broadleaf weeds in modern agriculture. Prometryne is a ubiquitous environmental pollutant in water and soil. It is frequently detected in groundwater, surface water, and even breast milk (Albanis et al., 1994; Papadopoulou-Mourkidou et al., 2004). Based on one classification scheme (Swann et al., 1983), the soil organic-carbon adsorption coefficient $\left(K_{o c}\right)$ value is within 311-614, indicating that Prometryne is expected to have moderate to low mobility in soil and may be adsorbed to solids and sediment suspended in water. $K_{o c}$ values are useful in predicting the mobility of organic soil contaminants; higher $K_{o c}$ values correlate to less mobile organic chemicals while lower $K_{o c}$ values correlate to more mobile organic chemicals. The $K_{o c}$ value is relatively constant for a particular compoud among soil samples from different origins. Zhou et al. (2009a) reported the quantification of Prometryne in water and soil samples by CPE using TX-114 as the surfactant coupled with HPLC-UV detection. In this method, nonionic surfactant TX-114 was first used to extract and pre-concentrate Prometryne from water and soil samples. The separation and determination of Prometryne were then carried out in an HPLC-UV system with isocratic elution using a detector set at $\lambda=254 \mathrm{~nm}$ wavelength. Under optimize conditions, the recovery rates of prometryne ranged from $92.84 \%$ to $99.23 \%$ in water and $85.48 \%$ to $93.67 \%$ in soil, respectively.

Tang et al. (2010) developed a CPE method for the determination of trace levels of triazole fungicides (tricyclazole, triadimefon, tebuconazole and diniconazole) in environmental waters. The triazole fungicides were extracted and preconcentrated using polyethylene glycol 600 monooleate (PEG600MO) as a low toxic and environmentally benign nonionic surfactant, and determined by HPLC-UV detection. The triazole fungicides were well separated on a reversed-phase kromasil ODS $\mathrm{C}_{18}$ column with gradient elution at ambient temperature and detected at $225 \mathrm{~nm}$. Since the surfactant-rich phase was compatible with the mobile phase, no additional washing step was required to remove the surfactant from the kromasil ODS $\mathrm{C}_{18}$ column. This study demonstrates that the nonionic surfactant PEG600MO is very effective for the extraction and separation of the triazole fungicides from environmental waters.

Organophosphorus pesticides (OPPs) are widely found in water resources. They are released into the environment from manufacturing, transportation and agriculture applications. OPPs, such as methyl and ethyl parathion, paraoxon and fenitrothion have been determined in river water samples by using CPE with the TX-114 prior to their separation by liquid chromatography; electrochemical detection permits suitable detection and quantification of these pesticides (Moreno-Cordero et al., 1998 ). Upon preconcentrating $15.0 \mathrm{ml}$ of water with a $1 \%$ concentration of $\mathrm{TX}-114$, the detection limit is $0.5 \mathrm{ng} \mathrm{mL}-1$. This sensitivity can be increased by preconcentrating $200 \mathrm{~mL}$ with $0.25 \% \mathrm{TX}-114$; under these conditions, the detection limits range between 0.03 for fenitrothion and $0.08 \mathrm{ng} \mathrm{mL}^{-1}$ in the case of paraoxon. The method could also be used in the determination of these analytes in drinking water, in which the maximum concentration permitted by the EU is 0.1 $\mathrm{ppb} /$ individual substance. 
Sanz and his coworkers (2004) developed to extract, preconcentrate and determine a mixture of eight organophosphorus pesticides (OPPs) (Chlorpyrifos, Diazinon, Dimethoate, Ethoprophos, Malathion, Methidathion, Parathion methyl and Paration ethyl) by using the POLE and Genapol X-080 as extractants with LC-UV detection. The results obtained in this study indicate that the use of Genapol X-080 provides better results than POLE for the extraction of OPPs using CPE. One problem with the UV detection is that pesticides absorb appreciably at wavelengths below $250 \mathrm{~nm}$ (DiCorcia \& Marchetti, 1991; Ellington et al.,2001), the same spectral region where many reactives and matrix-derived interferences absorb. For this reason, LC-UV analysis is generally more applicable in high-concentration formulations (Cho et al., 1997) or very clean environmental substrates. The extract is compatible with the mobile phase used in LC and provides overall satisfactory results for non-polar pesticides. It is faster than solid phase microextraction and since it is not necessary to evaporate the solvents, no analyte is lost as a result of the process. Recoveries between 70 and $100 \%$ were obtained for the majority of cases. Only Dimethoate and Ethoprophos were extracted with recoveries $<50 \%$.

Benomyl (BN), carbendazim (MBC), thiabendazole (TBZ) and fuberidazole (FB) are benzimidazole fungicides (BIFs). Such BIFs and their derivatives are used to protect several crops, both during field and post-harvest treatments. The majority of such substances are either applied directly to the soil, or they are sprayed the over crop fields and hence released to the environment. In this manner the fungicides can get into natural water as contaminants either directly or through agricultural land drainage. In order to estimate the environmental impact, the original substances and their metabolites need to be measured at very low concentration levels. An analytical method has been developed to determine the Benzimidazole fungicides and their residues (BN, MCB, TBZ and FB) in real water samples. The CPE methodology for these fungicides using non-ionic surfactant Genapol X-080 and POLE was used in combination with their analysis by RP-HPLC with direct fluorescence detection. The recoveries of fungicides obtained in spiked water samples ranged from $68 \%$ to $94 \%$ for Genapol and from $68 \%$ to $96 \%$ for POLE (Halko et al., 2004). CPE using non-ionic surfactant such as POLE and Genapol X-080 provides good extraction efficiency of the studied fungicides, as compared to the conventional extraction method, such as solid-phase extraction (SPE).

CPE of herbicides, including chlortoluron, metoxuron, chloridazon, simazine, propazine and atrazine, using Genapol-X-080 was previously employed as a preconcentration step prior to HPLC using micellar liquid chromatography and an aqueous mobile phase containing that same surfactant (Halko \& Hutta, 2002). In that work, no detection limits were reported, but the enrichment factors achieved ranged from 8 to 65 depending upon the specific herbicide.

Zhu et al. (2007) described a CPE methodology for the indirect determination of trichlorfon residue. Trichlorfon is one of the most widely used insecticides in rice, cotton, fruit tree, vegetables and tea tree. When trichlorfon was extracted by CPE method, its recovery was poor due to the fact that it is highly soluble in water. On the other hand, the surfactant TX100 absorbs in UV region and would interfere with the determination of trichlorfon by HPLC-UV method. Therefore, trichlorfon was directly extracted using the aqueous, followed by addition of benzidine and sodium perborate, 4-amino-4'-nitrobiphenyl was formed based on its catalytic effect. Then 4-amino-4'-nitrobiphenyl was separated and preconcentrated by CPE method, and then detected using a HPLC with UV detection. In 
addition, for the maximum absorption wavelengh of 4-amino-4'-nitrobiphenyl is at $365 \mathrm{~nm}$, Triton X-100 could not interfere with its determination.

Simultaneous determination by HPLC with electrochemical detection of Captan, Folpet and Captafol in river water samples has been described by Carabias-Martínez et al. (1996). To concentrate the fungicide residues, a CPE step employing the Triton X-114 was applied. Electrochemical detection with single and dual glassy-carbon electrodes was evaluated for possible amperometric detection of these fungicides; the reductive-oxidative detection mode with a dual electrode in the series configuration proved to be more appropriate than direct reductive detection with a single working electrode. Chromatographic elution of these fungicides requires a mobile phase with a relatively low organic solvent content $(45 \%, \mathrm{v} / \mathrm{v}$, acetonitrile-water). Under experimental conditions, not all the TX-114 is eluted from the chromatographic column: to remove the surfactant remaining in the stationary phase, a washing cycle with $100 \%$ acetonitrile $10 \mathrm{~min}$ was performed. In addition to the extraction preconcentration of the fungicides, the presence of TX-114 stabilises the fungicides and prevents their hydrolysis in aqueous medium. The addition of surfactant at the time of sample collection is a simple way to avoid losses of fungicide during the period of sample storage. Also in this case, electrochemical detection permits the simultaneous quantification of all three fungicides since spectrophotometric detection only allows the quantification of the fungicide Folpet.

Another method proposed by Pinto et al. (1995) was depends on a dual electrochemical (reductive-oxidative) detection. The presence of nitro and azo groups in the structure of organophosphorus compounds would allow their determination by reductive electrochemical detection as long as the dissolved oxygen is completely eliminated in order to avoid high residual current. This drawback can be readily overcome by oxidative electrochemical detection after transformation, by reduction of the analytes, in derivatives susceptible to later oxidation. Dual electrochemical detection (reductive-oxidative mode) was used for the liquid chromatographic analysis of OPPs (paraoxon (diethyl 4-nitrophenyl phosphate), methyl parathion (o, o-diethyl-o-(4-nitrophenyl) phosphorothioate), fenitrothion [o,o-dimethyl-o-(3-methyl-4-nitrophenyl)], and ethylparathion (o,o-diethyl-o-pnitrophenylthiophosphate) after CPE with the TX-114 (Pinto et al., 1995). Because the surfactant does not have electroactive groups in its structure, these electrochemical signals could be due to impurities in the TX-114 itself, arising in its synthesis; these can be detected directly or after reduction on the working electrodes.

Since many pesticides are colourless, a technique for yielding of coloured derivative of pesticide has been applied in the determination of pesticides in visible region. This technique is based on the derivative reaction of pesticide where the analytes are detected in visible region which is transparent to surfactants (Chen et al., 2008). Carbofuran can be hydrolysed to from 2,3-dihydro-2,2-dimethyl-7-benzofuranol (BF). BF is coupled with 4aminoantipyrene $(\mathrm{AP})$ in presence of potassium ferricyanide $\left[\mathrm{K}_{3} \mathrm{Fe}(\mathrm{CN})_{6}\right]$ to generate red coloured derivative (BFAP) having $\lambda=530 \mathrm{~nm}$. The $\mathrm{BF}$ molecule has one free phenolic hydroxyl group and no substitute in the para position pare to the hydroxyl group. CPE methodology and using TX-100 as extractant was applied as a preconcentration step prior to HPLC, the surfactant-rich phase containing BFAP was then analysed by HPLC in visible region. The coloured analytes are detected in visible region, in which the high back ground absorption of surfactant may not interfere with the determination of the analytes. On the other hand, when the determination is carried out by HPLC-UV system, the response of the 
coloured derivate is higher than that of original compound. This method can be used to determine other pesticides which could be hydrolysed into the phenolic compounds. Figure 3. shows Carbofuran hydrolysis and derivatization reaction.

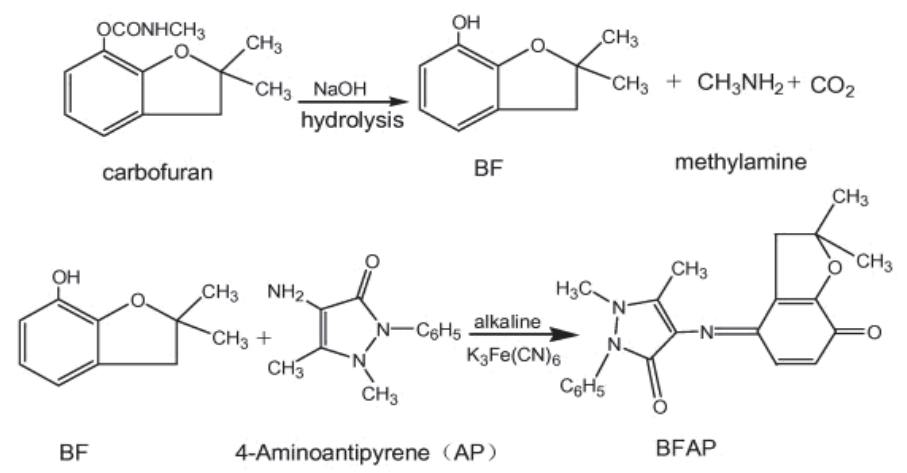

Fig. 3. Reaction mechanism of carbofuran with derivatising reagents (Chen et al., 2008).

Sulfonylurea herbicides are widely used for controlling weeds or grasses in farmland. Three sulfonylurea herbicides (metsulfuron-methyl (MSM), chlorsulfuron (CS), and bensulfuronmethyl (BSM)) in water, soil, and rice grain have been analyzed simultaneously by Wu et al. (2010). TX-114 and PEG-6000 were used for CPE separation of sulfonylurea herbicides in the samples. Impurities in the extracts of soil and rice grains did not interfere with the quantitative determination of MSM, CS, and BSM because the peaks were shown to be located at different places. Optimal extraction recovery for the three herbicides was observed at $12 \%$ sodium sulfate, with $92.3 \%, 93.6 \%$, and $94.5 \%$ recoveries were obtained for MSM, CS, and BSM, respectively.

Polychlorinated dibenzofurans (PCDF) are organic compounds with very toxic effects for humans and the environment. Fernández and his coworkers have applied CPE to analyze six polychlorinated dibenzofurans (PCDF). In this work, the methodology of cloud-point extraction, using two non-ionic surfactants oligoethylene glycol monoalkyl ether (Genapol $\mathrm{X}-080$ ) and polyoxyethylene-10-cetyl ether (Brij 56), is applied to the extraction and preconcentration of PCDF in sea water samples prior to their determination by HPLC with fluorescence detection. The surfactant-rich phase was analysed on a $4 \mu \mathrm{m}$ Nova-Pak C18 column $(15 \mathrm{~cm} \times 3.9 \mathrm{~mm}$ i.d.), with aqueous $85 \%$ methanol as the mobile phase and the recoveries are $68-105 \%$.

Micelle-mediated extraction with octyl-b-D-thioglucoside (OTG) has been raported by Saitoh et al. (2000). Many hydrophobic compounds are efficiently incorporated into the surfactant-rich phase separated from the aqueous surfactant solution with elimination of hydrophilic matrix components to the bulk aqueous phase. Because of the extremely small volume fraction of the surfactant-rich phase, the analytes can be highly concentrated, thus allowing great enhancement in the sensitivity of chromatographic analysis. However, the appearance of a large number of peaks because of the ultra-violet (UV) absorption of TX-114 or PONPE-7.5, which are mostly used for CPE, limits the subsequent detection method. The use of alkylglucoside surfactants instead of polyoxyethylene-type surfactants may solve these problems. An aqueous solution of octyl-b-D-thioglucoside (OTG) can be separated into 
bulk aqueous and surfactant-rich phases by adding an appropriate water-soluble polymer such as polyethylene glycol (PEG) or dextran derivatives. Since OTG has little UV absorption around $254 \mathrm{~nm}$, presence of the concentrated surfactant would not hinder UV detection of analytes. In an extended application, Saitoh et al. (2000) evaluated the possibility of isolating a wide range of organic analytes, including PAHs, alkylbenzenes, alkylphenols, chlorobenzenes, chlorophenols, phthalic esters, pesticides and steroid hormones with octyl-b-D-thioglucoside (OTG) followed by LC-UV detection. Micellemediated extraction with octyl-b-D-thioglucoside (OTG) is a viable and attractive method for extracting various organic compounds in aqueous solution prior to HPLC analysis. The surfactant-rich phase containing concentrated OTG could be directly introduced into the hygro-organic mobile phase of HPLC with UV detection. The application of this method greatly enhanced the signal intensity in the chromatogram while reducing the interference of matrix components.

Anionic surfactant micelle-mediated extraction (coacervation extraction) has been evaluated for isolation of Etofenprox before HPLC (Jia et al., 2006). The anionic surfactant sodium dodecylsulfonate (SDoS) has been used for extraction of Etofenprox from aqueous environmental samples and from biological samples by means of coacervation extraction. Genarally, nonionic and zwitterionic surfactants can be used for CPE. The cloud point refers to the phase separation of neutral surfactants induced by temperature. Cationic and anionic surfactants can be used for coacervation extraction. The term "coacervation" is reserved for the phase separation of ionic amphiphiles induced by other conditions. Cationic surfactants (alkyltrimethylammonium bromides) are known to undergo coacervation in the presence of saturated $\mathrm{NaCl}$ and 1-octanol. Anionic surfactants such as alkyl sulfates, sulfonates, and sulfosuccinates undergo $\mathrm{pH}$-induced coacervation. For extractions with cationic surfactants the main problem arises from the sharp dependence of the volume of the surfactant-rich phase obtained on the volume of the cosurfactant added, which can result in poor reproducibility (Jia et al., 2006). The recoveries obtained from five real samples ranged from 94.3 to $100.1 \%$.

Ding et al. (2009) analyzed the organophosphate pesticides in aqueous solution. A CPE utilizing polyoxyethylene 10 laurylether $\left(\mathrm{C}_{12} \mathrm{E}_{10}\right)$ has been developed to enrich the trace organophosphate pesticide in aqueous solution, including parathion-methyl and phoxime for rapid determination of pesticide residues. As the result reveals, CPE is a good technology with a high enrichment times on parathion-methyl and phoxime, which reaches 95 and 97 at most, respectively, and the CP-extraction yield can exceed $90 \%$, when using $5 \mathrm{~g} \mathrm{~L}^{-1} \mathrm{C}_{12} \mathrm{E}_{10}$ and $120 \mathrm{~g} \mathrm{~L}^{-1} \mathrm{Na}_{2} \mathrm{SO}_{4}$ at $35^{\circ} \mathrm{C}$. Combining CPE with HPLC, the method detect limit (MDL) of parathion-methyl and phoxime can reach $1 \mu \mathrm{g} \mathrm{L} \mathrm{L}^{-1}$.

Six herbicides in milk samples have been analyzed simultaneously (Wang et al., 2007). The feasibility of employing CPE as extraction and preconcentration method for the recovery of herbicides from milk samples followed by HPLC analysis has been demonstrated. An aqueous surfactant solution containing $60 \mathrm{~g} \mathrm{~L}^{-1}$ Tween 20 or Triton X-100 was heated with an appropriate concentration of $\left(\mathrm{NH}_{4}\right)_{2} \mathrm{SO}_{4}$ or $\mathrm{NaCl}$ for the extraction of herbicides. The extract was analyzed by HPLC subsequently. The results showed that the linear dynamic ranges of detection were 20-10000 $\mu \mathrm{g} \mathrm{L}-1$ for tralkoxydim, metribuzin and bromoxynil, 30-10000 $\mu \mathrm{g} \mathrm{L}^{-1}$ for mefenacet, and 50-10000 $\mu \mathrm{g} \mathrm{L}^{-1}$ for bensulfuron-methyl and nicosulfuron. The correlation coefficients were 0.9981-0.9997. The average recoveries of the six herbicides ranged from $85.09 \%$ to $96.74 \%$.The relative standard deviations for the six herbicides were in the range of $1.90 \%-3.98 \%$. The limits of detection for the six pesticides were lower than the maximum residue limits (MRL) of China. 


\begin{tabular}{|c|c|c|c|c|c|c|}
\hline Pesticide & $\begin{array}{l}\text { Method/ } \\
\text { Surfactant/Matrix }\end{array}$ & $\begin{array}{l}\text { Linear } \\
\text { range }\end{array}$ & & LOD & & Reference \\
\hline Carbaryl & $\begin{array}{l}\text { Uv-vis/TX114/ } \\
\text { water }\end{array}$ & $10-500$ & $\mu \mathrm{g} \mathrm{L}^{-1}$ & 7.0 & $\mu \mathrm{g} \mathrm{L}^{-1}$ & $\begin{array}{l}\text { (Melchert \& } \\
\text { Rocha, 2009) }\end{array}$ \\
\hline $\begin{array}{l}\text { Napropamide } \\
\text { Thiabendazole }\end{array}$ & $\begin{array}{l}\text { FD*/Genapol X } \\
\text { 080/Water \& Soil }\end{array}$ & NR & & 0.2 & $\begin{array}{l}\mu \mathrm{g} \mathrm{L}^{-1} \\
\mu \mathrm{g} \mathrm{L}^{-1}\end{array}$ & $\begin{array}{l}(\text { Stangl \& } \\
\text { Niessner, } \\
1994)\end{array}$ \\
\hline Carbaryl & $\begin{array}{l}\text { Uv-vis/TX114/ } \\
\text { Water \& vegetable }\end{array}$ & $0.1-7.0$ & $m g L^{-1}$ & 50 & $\mu \mathrm{g} \mathrm{L}^{-1}$ & $\begin{array}{l}\text { (Santalad et al. } \\
2008)\end{array}$ \\
\hline Napropamide & $\begin{array}{l}\text { FD*/Genapol } \\
\text { X-080 \&X- } \\
150 / \text { ultrapure } \\
\text { water and natural } \\
\text { samples. }\end{array}$ & NR & & 0.2 & $n g \mathrm{~L}^{-1}$ & $\begin{array}{l}\text { (Stangl \& } \\
\text { Niessner, 1995) }\end{array}$ \\
\hline DDT & $\begin{array}{l}\text { HPLC/Igepal- } \\
\text { ICO-630/ } \\
\text { TX-114/Soil }\end{array}$ & NR & & NR & & $\begin{array}{l}\text { (Evdokimov \& } \\
\text { von } \\
\text { Wandruszka, } \\
1998)\end{array}$ \\
\hline $\begin{array}{l}\text { Folfet } \\
\text { Captan } \\
\text { Captafol }\end{array}$ & $\begin{array}{l}\text { HPLC-ED/ } \\
\text { TX-114/River } \\
\text { water }\end{array}$ & NR & & $\begin{array}{l}4.0 \\
4.0 \\
6.0\end{array}$ & $\begin{array}{l}\mu g \mathrm{~L}^{-1} \\
\mu g \mathrm{~L}^{-1} \\
\mu \mathrm{g} \mathrm{L}^{-1}\end{array}$ & $\begin{array}{l}\text { (Carabias - } \\
\text { Martínez et al., } \\
1996)\end{array}$ \\
\hline $\begin{array}{l}4,4^{\prime}-\text { DDD } \\
\text { Dieldrin } \\
4,4^{\prime}-\text { DDT } \\
2,4^{\prime}-\mathrm{DDT} \\
4,4^{\prime}-\text { DDE } \\
\text { Aldrin }\end{array}$ & $\begin{array}{l}\text { HPLC-UV/ } \\
\text { Cetyl mixture/ } \\
\text { Soil sample \& } \\
\text { aged soils. }\end{array}$ & $80-800$ & $n g g^{-1}$ & \begin{tabular}{|l|}
108.8 \\
793.2 \\
167.2 \\
86.4 \\
135.6 \\
806.4
\end{tabular} & $\begin{array}{l}\text { ng g-1 } \\
n g g^{-1} \\
n g g^{-1} \\
n g g^{-1} \\
n g g^{-1} \\
n g g^{-1}\end{array}$ & $\begin{array}{l}\text { (Moreno et al., } \\
2006)\end{array}$ \\
\hline $\begin{array}{l}4,4^{\prime}-\mathrm{DDD} \\
\text { Dieldrin } \\
4,4^{\prime}-\mathrm{DDT} \\
2,4^{\prime}-\mathrm{DDT} \\
4,4^{\prime}-\mathrm{DDE} \\
\text { Aldrin }\end{array}$ & $\begin{array}{l}\text { HPLC-UV/ } \\
\text { Stearyl mixture/ } \\
\text { Soil sample \& } \\
\text { aged soils. }\end{array}$ & $80-800$ & $n g g^{-1}$ & $\begin{array}{l}269.6 \\
734.0 \\
171.6 \\
285.2 \\
150.8 \\
593.2\end{array}$ & $\begin{array}{l}\text { ng g-1 } \\
\text { ng g-1 } \\
\text { ng g-1 } \\
\text { ng g-1 } \\
\text { ng g-1 } \\
\text { ng g-1 }\end{array}$ & $\begin{array}{l}\text { (Moreno et al., } \\
2006)\end{array}$ \\
\hline $\begin{array}{l}\text { Metsulfuron } \\
\text { Chlorsulfuron } \\
\text { Bensulfuron }\end{array}$ & $\begin{array}{l}\text { HPLC-UV } \\
\text { TX-114/ } \\
\text { Water, } \\
\text { soil\& rice grains } \\
\end{array}$ & $\begin{array}{l}0.004-2.0 \\
0.004-2.0 \\
0.004-2.0\end{array}$ & $\begin{array}{l}\mathrm{mg} \mathrm{L}^{-1} \\
\mathrm{mg} \mathrm{L}^{-1} \\
\mathrm{mg} \mathrm{L}^{-1}\end{array}$ & \begin{tabular}{|l|}
$0.8-4.0$ \\
$1.2-6.0$ \\
$0.8-4.0$
\end{tabular} & $\begin{array}{l}\mu \mathrm{g} \mathrm{kg}^{-1} \\
\mu \mathrm{g} \mathrm{kg}^{-1} \\
\mu \mathrm{g} \mathrm{kg}^{-1}\end{array}$ & $\begin{array}{lll}(\mathrm{Wu} & \text { et } & \text { al., } \\
2010) & & \end{array}$ \\
\hline $\begin{array}{l}\text { Arprocarb } \\
\text { Carbofuran } \\
\text { Isoprocarb } \\
\text { Fenobucarb } \\
\end{array}$ & $\begin{array}{l}\text { HPLC-UV/ } \\
\text { TX-100/ } \\
\text { Corn }\end{array}$ & $\begin{array}{l}8 \times 10^{-4}-0.5 \\
8 \times 10^{-4}-0.5 \\
8 \times 10^{-4}-0.5 \\
2 \times 10^{-3}-0.5 \\
\end{array}$ & $\begin{array}{l}\mathrm{mg} \mathrm{L}^{-1} \\
\mathrm{mg} \mathrm{L}^{-1} \\
\mathrm{mg} \mathrm{L}^{-1} \\
\mathrm{mg} \mathrm{L}^{-1}\end{array}$ & $\begin{array}{l}2 \times 10^{-4} \\
2 \times 10^{-4} \\
2 \times 10^{-4} \\
5 \times 10^{-4}\end{array}$ & $\begin{array}{l}\mathrm{mg} \mathrm{L}^{-1} \\
\mathrm{mg} \mathrm{L}^{-1} \\
\mathrm{mg} \mathrm{L}^{-1} \\
\mathrm{mg} \mathrm{L}^{-1}\end{array}$ & $\begin{array}{l}\text { (Zhou et al., } \\
\text { 2009a) }\end{array}$ \\
\hline Prometryne & $\begin{array}{l}\text { HPLC-UV/ } \\
\text { TX-114/ } \\
\text { Water\&Soil }\end{array}$ & $0.016-10$ & $\mu \mathrm{g} \mathrm{mL}^{-1}$ & $\begin{array}{l}3.5 \\
4.0\end{array}$ & $\begin{array}{l}\mu g \mathrm{~L}^{-1} \\
\mu \mathrm{g} \mathrm{L} \mathrm{L}^{-1}\end{array}$ & $\begin{array}{l}\text { (Zhou et al., } \\
2009 b)\end{array}$ \\
\hline
\end{tabular}




\begin{tabular}{|c|c|c|c|c|c|c|}
\hline $\begin{array}{l}\text { Tricyclazole, } \\
\text { Triadimefon, } \\
\text { Tebuconazole } \\
\text { Diniconazole }\end{array}$ & $\begin{array}{l}\text { PEG600MO/ } \\
\text { Tap\& River water }\end{array}$ & $\begin{array}{l}0.05-20 \\
0.05-20 \\
0.05-20 \\
0.05-20\end{array}$ & $\begin{array}{l}\mu \mathrm{g} \mathrm{L}^{-1} \\
\mu \mathrm{g} \mathrm{L}^{-1} \\
\mu \mathrm{g} \mathrm{L}^{-1} \\
\mu \mathrm{g} \mathrm{L}^{-1}\end{array}$ & \begin{tabular}{|l|}
6.8 \\
23.2 \\
34.5 \\
21.6
\end{tabular} & $\begin{array}{l}\text { ng } L^{-1} \\
\text { ng } L^{-1} \\
\text { ng } L^{-1} \\
\text { ng } L^{-1}\end{array}$ & $\begin{array}{l}\text { (Tang et al., } \\
2010)\end{array}$ \\
\hline $\begin{array}{l}\text { Chlorpyrifos } \\
\text { Diazinon } \\
\text { Dimethoate, } \\
\text { Ethoprophos } \\
\text { Malathion, } \\
\text { Methidathion } \\
\text { Parathion } \\
\text { Paration ethyl }\end{array}$ & $\begin{array}{l}\text { LC-UV/ } \\
\text { POLE/ } \\
\text { Aqueous } \\
\text { samples }\end{array}$ & $\begin{array}{l}50-3000 \\
50-3000 \\
50-3000 \\
300-3000 \\
500-3000 \\
50-3000 \\
50-3000 \\
100-3000\end{array}$ & $\begin{array}{l}\text { ng mL-1 } \\
\text { ng mL-1 } \\
\text { ng mL-1 } \\
\text { ng mL } L^{-1} \\
\text { ng mL } L^{-1} \\
\text { ng mL-1 } \\
\text { ng mL-1 } \\
\text { ng mL } L^{-1}\end{array}$ & $\begin{array}{ll}1.86 & \mathrm{n} \\
1.65 & \mathrm{n} \\
1.86 & \mathrm{n} \\
28.45 & \mathrm{n} \\
0.88 & \mathrm{n} \\
2.03 & \mathrm{n} \\
2.96 & \mathrm{n} \\
3.54 & \mathrm{n}\end{array}$ & $\begin{array}{l}\text { ng } \mathrm{mL}^{-1} \\
\text { ng } \mathrm{mL}^{-1} \\
\text { ng } \mathrm{mL}^{-1} \\
\text { ng } \mathrm{mL}^{-1} \\
\text { ng } \mathrm{mL}^{-1} \\
\text { ng } \mathrm{mL}^{-1} \\
\text { ng } \mathrm{mL}^{-1} \\
\text { ng } \mathrm{mL}^{-1}\end{array}$ & \begin{tabular}{|l} 
(Sanz et al., \\
$2004)$
\end{tabular} \\
\hline $\begin{array}{l}\text { Chlorpyrifos } \\
\text { Diazinon } \\
\text { Dimethoate, } \\
\text { Ethoprophos, } \\
\text { Malathion, } \\
\text { Methidathion } \\
\text { Parathion } \\
\text { Paration ethyl }\end{array}$ & $\begin{array}{l}\text { LC-UV/ } \\
\text { Genapol X080/ } \\
\text { Aqueous } \\
\text { samples }\end{array}$ & $\begin{array}{l}25-2500 \\
25-2500 \\
25-2500 \\
100-2500 \\
250-2500 \\
25-2500 \\
25-2500 \\
50-2500 \\
\end{array}$ & $\begin{array}{l}\text { ng } \mathrm{mL}^{-1} \\
\mathrm{ng} \mathrm{mL}^{-1} \\
\mathrm{ng} \mathrm{mL}^{-1} \\
\mathrm{ng} \mathrm{mL}^{-1} \\
\mathrm{ng} \mathrm{mL}^{-1} \\
\mathrm{ng} \mathrm{mL}^{-1} \\
\mathrm{ng} \mathrm{mL}^{-1} \\
\mathrm{ng} \mathrm{mL}^{-1}\end{array}$ & $\begin{array}{l}0.6 \\
0.8 \\
2.1 \\
0.7 \\
1.4 \\
2.6 \\
1.0 \\
2.2 \\
\end{array}$ & $\begin{array}{l}\text { ng } \mathrm{mL}^{-1} \\
\text { ng } \mathrm{mL}^{-1} \\
\text { ng } \mathrm{mL}^{-1} \\
\text { ng } \mathrm{mL}^{-1} \\
\text { ng } \mathrm{mL}^{-1} \\
\text { ng } \mathrm{mL}^{-1} \\
\text { ng } \mathrm{mL}^{-1} \\
\text { ng } \mathrm{mL}^{-1}\end{array}$ & $\begin{array}{l}\text { (Sanz et al., } \\
2004)\end{array}$ \\
\hline $\begin{array}{l}\text { Polychlorinated } \\
\text { dibenzofurans } \\
(\mathrm{PCDF})\end{array}$ & $\begin{array}{l}\text { HPLC-FD*/ } \\
\text { Genepol X080 \& } \\
\text { Brij 56/Seawater }\end{array}$ & $0.17-27.2$ & $\mu \mathrm{g} \mathrm{mL}^{-1}$ & $0.5-27.5$ & $\mathrm{ng} \mathrm{L}^{-1}$ & $\begin{array}{l}\text { (Fernández et } \\
\text { al., 1999) }\end{array}$ \\
\hline $\begin{array}{l}\text { Benomyl } \\
\text { Carbendazim } \\
\text { Thiabendazole } \\
\text { Fuberidazole } \\
\end{array}$ & \begin{tabular}{l|} 
HPLC-FD*/ \\
POLE/ \\
Water
\end{tabular} & \begin{tabular}{|l|}
$10-200$ \\
$10-200$ \\
$1.0-100$ \\
$0.01-0.5$ \\
\end{tabular} & $\begin{array}{l}\mu \mathrm{g} \mathrm{L}^{-1} \\
\mu \mathrm{g} \mathrm{L}^{-1} \\
\mu \mathrm{g} \mathrm{L}^{-1} \\
\mu \mathrm{g} \mathrm{L}^{-1}\end{array}$ & $\begin{array}{l}7.1 \\
9.2 \\
4.3 \\
4.5 \\
\end{array}$ & $\begin{array}{l}\mu \mathrm{g} \mathrm{L}^{-1} \\
\mu \mathrm{g} \mathrm{L}^{-1} \\
\mu \mathrm{g} \mathrm{L}^{-1} \\
\mu \mathrm{g} \mathrm{L}^{-1}\end{array}$ & $\begin{array}{l}\text { (Halko et al., } \\
2004)\end{array}$ \\
\hline $\begin{array}{l}\text { Benomyl } \\
\text { Carbendazim } \\
\text { Thiabendazole } \\
\text { Fuberidazole }\end{array}$ & $\begin{array}{l}\text { HPLC-FD*/ } \\
\text { Genopol/ } \\
\text { Water }\end{array}$ & $\begin{array}{l}10-200 \\
10-200 \\
1-100 \\
0.01-0.5\end{array}$ & $\begin{array}{c}\mu \mathrm{g} \mathrm{L}^{-1} \\
\mu \mathrm{g} \mathrm{L}^{-1} \\
\mu \mathrm{g} \mathrm{L}^{-1} \\
\mu \mathrm{g} \mathrm{L}^{-1}\end{array}$ & \begin{tabular}{|l|}
5.8 \\
6.4 \\
0.13 \\
0.08 \\
\end{tabular} & $\begin{array}{l}\mu \mathrm{g} \mathrm{L}^{-1} \\
\mu \mathrm{g} \mathrm{L}^{-1} \\
\mu \mathrm{g} \mathrm{L}^{-1} \\
\mu \mathrm{g} \mathrm{L}^{-1}\end{array}$ & $\begin{array}{l}\text { (Halko et al., } \\
2004)\end{array}$ \\
\hline $\begin{array}{l}\text { Paraoxon } \\
\text { Methylparathion } \\
\text { Fenitrothion } \\
\text { Ethylparathion }\end{array}$ & $\begin{array}{l}\text { HPLC-DED } \\
\text { TX-114/ } \\
\text { Water }\end{array}$ & \begin{tabular}{|l|}
$0.99-60$ \\
$0.97-58$ \\
$0.80-47$ \\
$0.96-58$ \\
\end{tabular} & $\begin{array}{l}\mathrm{ppb} \\
\mathrm{ppb} \\
\mathrm{ppb} \\
\mathrm{ppb}\end{array}$ & $\begin{array}{l}0.35 \\
0.21 \\
0.18 \\
0.33 \\
\end{array}$ & $\begin{array}{l}\mathrm{ppb} \\
\mathrm{ppb} \\
\mathrm{ppb} \\
\mathrm{ppb}\end{array}$ & $\begin{array}{l}\text { (Pinto et al., } \\
1995)\end{array}$ \\
\hline $\begin{array}{l}p, p^{\prime} \text {-DDD } \\
p, p^{\prime} \text {-DDE }\end{array}$ & \begin{tabular}{|l|} 
HPLC/OGT/ \\
Water
\end{tabular} & NR & & NR & & $\begin{array}{l}\text { (Saitoh et al., } \\
2000)\end{array}$ \\
\hline $\begin{array}{l}\text { Tralkoxydim, } \\
\text { Metribuzin } \\
\text { Bromoxynil, } \\
\text { Mefenacet } \\
\text { Bensulfuron- } \\
\text { methylsulfuron } \\
\text { Nicosulfuron } \\
\end{array}$ & $\begin{array}{l}\text { HPLC/Tween } 20 \\
\text { or TX 100/ } \\
\text { Milk } \\
\\
\end{array}$ & \begin{tabular}{|l|}
$20-10000$ \\
$20-10000$ \\
$20-10000$ \\
$30-10000$ \\
$50-10000$ \\
$50-10000$ \\
$50-10000$ \\
\end{tabular} & $\begin{array}{l}\mu g \text { L}^{-1} \\
\mu g \mathrm{~L}^{-1} \\
\mu g \mathrm{~L}^{-1} \\
\mu g \mathrm{~L}^{-1} \\
\mu g \mathrm{~L}^{-1} \\
\mu g \mathrm{~L} \mathrm{~L}^{-1} \\
\mu \mathrm{g} \mathrm{L}^{-1}\end{array}$ & $\begin{array}{l}\text { NR } \\
\text { NR } \\
\text { NR } \\
\text { NR } \\
\text { NR } \\
\text { NR } \\
\text { NR } \\
\end{array}$ & & $\begin{array}{l}\text { (Wang et al., } \\
2007)\end{array}$ \\
\hline $\begin{array}{l}\text { Parathion-methyl } \\
\text { Phoxime }\end{array}$ & \begin{tabular}{|l|} 
10-laurylether \\
/aqueous solution
\end{tabular} & NR & & $\begin{array}{l}1.0 \\
1.0\end{array}$ & $\begin{array}{l}\mu \mathrm{g} \mathrm{L}^{-1} \\
\mu \mathrm{g} \mathrm{L}^{-1}\end{array}$ & $\begin{array}{l}\text { (Ding et al., } \\
\text { 2009) }\end{array}$ \\
\hline
\end{tabular}




\begin{tabular}{|c|c|c|c|c|c|c|}
\hline Trichlorfon & $\begin{array}{l}\text { HPLC/TX-100/ } \\
\text { Cabbage }\end{array}$ & $0.01-0.2$ & $\mathrm{mg} \mathrm{L}^{-1}$ & 2.0 & $\mu \mathrm{g} \mathrm{L}^{-1}$ & $\begin{array}{l}\left(\begin{array}{l}\text { Zhu } \\
2007)\end{array}\right. \\
\text { et al., }\end{array}$ \\
\hline Etofenprox & $\begin{array}{l}\text { HPLC/ SDoS/ } \\
\text { Water, Urine \& } \\
\text { Beer }\end{array}$ & $0.04-2.0$ & $\mathrm{mg} \mathrm{L}^{-1}$ & 0.004 & $\mathrm{mg} \mathrm{L}^{-1}$ & (Jia et al., 2006) \\
\hline $\begin{array}{l}\text { Phorate, } \\
\text { Diazinon, } \\
\text { Parathion } \\
\text { Fenthion } \\
\text { Quinalphos }\end{array}$ & $\begin{array}{l}\text { GC/TX-114/ } \\
\text { Human urine }\end{array}$ & \begin{tabular}{|l|}
$0.10-20$ \\
$0.10-20$ \\
$0.10-20$ \\
$0.10-20$ \\
$0.10-20$ \\
\end{tabular} & $\begin{array}{l}n g \mathrm{~mL}^{-1} \\
\mathrm{ng} \mathrm{mL} \mathrm{m}^{-1} \\
\mathrm{ng} \mathrm{mL} \mathrm{m}^{-1} \\
\mathrm{ng} \mathrm{mL}-1 \\
\mathrm{ng} \mathrm{mL}-1\end{array}$ & \begin{tabular}{|l|}
0.07 \\
0.04 \\
0.08 \\
0.07 \\
0.07
\end{tabular} & $\begin{array}{l}\mathrm{ng} \mathrm{mL}^{-1} \\
\mathrm{ng} \mathrm{mL^{-1 }} \\
\mathrm{ng} \mathrm{mL^{-1 }} \\
\mathrm{ng} \mathrm{mL} L^{-1} \\
\mathrm{ng} \mathrm{mL} L^{-1}\end{array}$ & (Jia et al., 2008) \\
\hline Disulfoton & $\begin{array}{l}\text { GC/ TX-114/ } \\
\text { Surface water }\end{array}$ & $3.9-150$ & $\mu \mathrm{g} \mathrm{L}^{-1}$ & 1.2 & $\mu \mathrm{g} \mathrm{L}^{-1}$ & $\begin{array}{l}\text { Faria et al. } \\
2007\end{array}$ \\
\hline $\begin{array}{l}\text { Fenitrothion } \\
\text { Chlorpirifos } \\
\text { Parathion } \\
\text { Methidathion }\end{array}$ & $\begin{array}{l}\text { GC/TX-114/ } \\
\text { Honey }\end{array}$ & $\begin{array}{l}1.0-1000 \\
0.3-1000 \\
1.0-1000 \\
1.0-1000 \\
\end{array}$ & $\begin{array}{l}\text { ng g-1 } \\
\text { ng g-1 } \\
\text { ng g-1 } \\
\text { ng g-1 }\end{array}$ & $\begin{array}{l}0.06 \\
0.03 \\
0.09 \\
0.47\end{array}$ & $\begin{array}{l}\text { ng g-1 } \\
\text { ng g-1 } \\
\text { ng g-1 } \\
\text { ng g-1 }\end{array}$ & $\begin{array}{l}\text { (Fontana et al., } \\
2010)\end{array}$ \\
\hline $\begin{array}{l}\text { Dichlorvos } \\
\text { Methamidophos } \\
\text { Acephate } \\
\text { Diazinon } \\
\text { Dimethoate, } \\
\text { Chlorpyrifos } \\
\text { Parathion-methyl } \\
\text { Malathion } \\
\text { Parathion-ethyl } \\
\end{array}$ & $\begin{array}{l}\text { GC/PEG 6000/ } \\
\text { Fruit juice }\end{array}$ & \begin{tabular}{|l|}
$5.0-200$ \\
$5.5-200$ \\
$8.0-200$ \\
$4.0-200$ \\
$5.5-200$ \\
$4.0-200$ \\
$4.0-200$ \\
$4.0-200$ \\
$5.0-200$ \\
\end{tabular} & $\begin{array}{l}\mu g \mathrm{~kg}^{-1} \\
\mu \mathrm{g} \mathrm{kg}{ }^{-1} \\
\mu \mathrm{g} \mathrm{kg} \mathrm{kg}^{-1} \\
\mu \mathrm{g} \mathrm{kg}{ }^{-1} \\
\mu \mathrm{g} \mathrm{kg}{ }^{-1} \\
\mu \mathrm{g} \mathrm{kg}{ }^{-1} \\
\mu \mathrm{g} \mathrm{kg}^{-1} \\
\mu \mathrm{g} \mathrm{kg}^{-1} \\
\mu \mathrm{g} \mathrm{kg}^{-1}\end{array}$ & $\begin{array}{l}1.5 \\
2.0 \\
3.0 \\
0.5 \\
2.0 \\
1.0 \\
1.0 \\
1.0 \\
1.5 \\
\end{array}$ & $\begin{array}{l}\mu \mathrm{g} \mathrm{kg}^{-1} \\
\mu \mathrm{g} \mathrm{kg}^{-1} \\
\mu \mathrm{g} \mathrm{kg}^{-1} \\
\mu \mathrm{g} \mathrm{kg} \mathrm{kg}^{-1} \\
\mu \mathrm{g} \mathrm{kg}{ }^{-1} \\
\mu \mathrm{g} \mathrm{kg}{ }^{-1} \\
\mu \mathrm{g} \mathrm{kg}{ }^{-1} \\
\mu \mathrm{g} \mathrm{kg}^{-1} \\
\mu \mathrm{g} \mathrm{kg}^{-1}\end{array}$ & $\begin{array}{l}\text { (Zhau et al., } \\
2011)\end{array}$ \\
\hline $\begin{array}{l}\text { Cyclopentadiene } \\
\text { Aimazine } \\
\text { Atrazine } \\
\text { Alachlor } \\
\text { Metolachlor } \\
\text { Butachlor }\end{array}$ & $\begin{array}{l}\text { GC/TX-114/ } \\
\text { Water }\end{array}$ & \begin{tabular}{|l|}
$5-4000$ \\
$1-4000$ \\
$0.5-4000$ \\
$0.5-4000$ \\
$0.1-4000$ \\
$0.5-4000$ \\
\end{tabular} & $\begin{array}{l}\mu g \mathrm{~L}^{-1} \\
\mu \mathrm{g} \mathrm{L^{-1 }} \\
\mu \mathrm{g} \mathrm{L^{-1 }} \\
\mu g \mathrm{~L}^{-1} \\
\mu g \mathrm{~L}^{-1} \\
\mu \mathrm{g} \mathrm{L}^{-1}\end{array}$ & $\begin{array}{l}481.5 \\
97.1 \\
19.6 \\
31.2 \\
6.59 \\
33.9 \\
\end{array}$ & $\begin{array}{l}\text { ng L-1 } \\
\text { ng L-1 } \\
\text { ng L-1 } \\
\text { ng L-1 } \\
\text { ng L-1 } \\
\text { ng L-1 }\end{array}$ & $\begin{array}{l}(\text { Takagai \& } \\
\text { Hinze, 2009) }\end{array}$ \\
\hline $\begin{array}{l}\text { Organochlorine } \\
\text { Pyrethroid }\end{array}$ & $\begin{array}{l}\text { GC/TX100/ } \\
\text { Viscum coloratum }\end{array}$ & \begin{tabular}{|l|}
$5-500$ \\
$10-1000$ \\
\end{tabular} & $\begin{array}{l}\mu g \mathrm{~L}^{-1} \\
\mu \mathrm{g} \mathrm{L}-1\end{array}$ & $\begin{array}{l}1.5-7.5 \\
1.5-7.5 \\
\end{array}$ & $\begin{array}{l}\mu g \mathrm{~kg}^{-1} \\
\mu \mathrm{g} \mathrm{kg-1}\end{array}$ & $\begin{array}{l}\text { (Zhang et al., } \\
2009)\end{array}$ \\
\hline $\begin{array}{l}\text { Pericyazine } \\
\text { Chlorpromazine } \\
\text { Fluphenazine }\end{array}$ & $\begin{array}{l}\text { GC/TX-114/ } \\
\text { Human serum }\end{array}$ & $\begin{array}{l}12.3-82.1 \\
9.0-90.3 \\
14.9-37.3 \\
\end{array}$ & $\begin{array}{c}\text { nmol } \\
\text { nmol } \\
\text { nmol } \\
\end{array}$ & \begin{tabular}{|l|}
3 \\
3 \\
3 \\
\end{tabular} & $\begin{array}{l}\text { nmol } \\
\text { nmol } \\
\text { nmol }\end{array}$ & $\begin{array}{l}\text { (Ohashi et al., } \\
2004)\end{array}$ \\
\hline $\begin{array}{l}\text { Ametryne } \\
\text { Terbutryne } \\
\text { Prometryne } \\
\text { Simazine } \\
\text { Atrazine } \\
\text { Propazine }\end{array}$ & $\begin{array}{l}\text { CE/TX-114/ } \\
\text { Drinking } \\
\text { \& River water }\end{array}$ & \begin{tabular}{|l|}
$25-500$ \\
$26-510$ \\
$26-520$ \\
$109-2180$ \\
$66-1310$ \\
$51-1020$ \\
\end{tabular} & $\begin{array}{l}\mu \mathrm{g} \mathrm{L}^{-1} \\
\mu \mathrm{g} \mathrm{L}^{-1} \\
\mu \mathrm{g} \mathrm{L}^{-1} \\
\mu \mathrm{g} \mathrm{L}^{-1} \\
\mu \mathrm{g} \mathrm{L}^{-1} \\
\mu \mathrm{g} \mathrm{L}^{-1}\end{array}$ & $\begin{array}{l}\text { NR } \\
\text { NR } \\
\text { NR } \\
\text { NR } \\
\text { NR } \\
\text { NR }\end{array}$ & & $\begin{array}{l}\text { (Carabias - } \\
\text { Martínez et al., } \\
1999)\end{array}$ \\
\hline
\end{tabular}

*FD: fluorescence detection and UV: ultraviolet detection.

Table 3. Cloud point extraction (CPE) applications for the determination of pesticide analytes. 


\subsection{Gas chromatography}

The application of CPE as a preconcentration step prior to gas chromatography (GC) or GCmass spectrometry (GC/MS) has found very little application due to the viscous nature of the surfactant, which endangered blocking of the capillary column. The primary reason for this stems from the fact that direct introduction of the surfactant-rich extractant phase into a GC system causes difficulties (Carabias-Martinez et al., 2000; Fröschl et al., 1997; Faria et al., 2007; Zygoura et al., 2005; Giokas et al., 2005; Sikalos \& Paleologos, 2005; Paleologos et al., 2006; Jia et al., 2008; Ohashi et al., 2004; Shen \& Shao, 2006). Namely, the surfactant can (i) adsorb onto (coat) the stationary phase and alter its polarity which causes changing nonreproducible analyte retention times with subsequent injections and/or (ii) it self elute as a series of peaks over a period of time from the column such that it overlaps with and obscures the analyte peak(s) of interest. In addition, it was thought that the introduction of the surfactant-rich extractant phase could "clog or block" the GC column. Several approaches have been employed to circumvent such difficulties. The first involves the use of mini-column liquid chromatography to separate and recover the target analyte(s) from the surfactant-rich extractant phase. Cation exchangers or silica gel and Florisil stationary phases have been employed in conjunction with aqueous methanolic, methanol-hexane or hexane mobile phases for this purpose (Fröschl et al., 1997; Faria et al., 2007). Sikalos and coworker (2005) created a breakthrough on this problem. They applied microwaves or sonication to back-extract analytes from the surfactant-rich phase into a water immiscible solvent prior to GC-flame ionization detection (FID) without any supplemental cleanup. Analogous back-extraction preceded GC analysis of UV-filters after CPE recently reported by Giokas et al. (2005) and of diethylhexyladipate and acetyltributylcitrate by Zygoura and coworkers (2005). After the components of a mixture are separated using gas chromatography, they must be detected as they exit the GC column. There exist a number of detectors, which can be used in GC. Different detectors give different types of selectivity. When organic molecules that contain electronegative functional groups, such as halogens, phosphorus, and nitro groups pass by the detector, they capture some of the electrons and reduce the current measured between the electrodes. Fröschl et al. (1997) reported the use of TX-100 in the preconcentration of polychlorinated biphenyls (PCBs) from water and extensive clean-up with two columns (Silica gel and Florisil) prior to GC analysis with electron capture detector (ECD). After the preconcentration of PCBs from water, the surfactant-rich phase passes through a silica gel column and is eluted with n-hexane. Then a small volume of eluate is collected. The rest of TX-100 in the eluate is removed by a second column filled with Florisil column. After the two clean-up procedures, the surfactant is eliminated completely and the final eluate is injected into GC-ECD for further analysis. The recoveries of PCBs obtained by CPE were compared with those obtained by liquid-liquid extraction. Both methods are comparable with recoveries ranging $86-116 \%$ for spiked ultrapure and tap water samples. The micellar extraction for PCBs is superior to the liquid-liquid extraction (LLE) for land fill seepage water.

Cloud point extraction coupled with microwave-assisted backextraction has been combined with GC-FPD successfully. The preconcentration of organophosphorous pesticides (OPPs) (phorate, diazinon, parathion-methyl, fenthion and quinalphos) from human urine samples by CPE coupled with microwave-assisted back-extraction prior to gas chromatography with flame photometry detection (GC-FPD) analysis has been developed by Jia et al. (2008). The preconcentrated analytes were back-extracted from the obtained surfactant-rich phase into isooctane by short-term microwave application. The isooctane solution obtained from back- 
extraction was centrifuged for further cleanup and then directly injected into the GC. A preconcentration factor of 50 was obtained for these five OPPs extracted from only $10 \mathrm{~mL}$ of a sample. Precision was also good; the relative standard deviations (RSDs) were less than $9 \%$. The method showed to be potential for biological monitoring. Compared with solid phase micro extraction (SPME), the proposed method only need some cheap surfactant and does not require special instrument. The LODs of this method are lower than the others.

Disulfoton [O,O-diethyl-S-[2-(ethylthio)ethyl]-phosphorodithioate] is a systemic insecticide and acaricide, also marketed as Di-Syston. Faria et al. (2007) reported the use of TX-114 in the preconcentration of Disulfoton from surface water and extensive clean-up with two columns (Silica gel and Florisil column) prior to GC analysis with flame ionization detector (FID). A cleanup stage is essential for analysis by GC using the cloud-point methodology. The presence of surfactant molecules can lead to rapid deterioration of the analytical column. After the preconcentration of disulfoton from water, the surfactant-rich phase passes through a silica gel column and is eluted with methanol:hexane (1:1). Then a small volume of eluate is collected. The rest of Triton X-114 in the eluate is removed by a second column filled with Florisil. After the two clean-up procedures, the surfactant is eliminated completely and the final eluate is injected into GC-FID. The recoveries of PCBs obtained by CPE were compared with those obtained by LL extraction. Both methods are comparable with recoveries ranging $86-116 \%$ for spiked ultra-pure and tap water samples.

Ohashi et al. (2004) studied three non-ionic surfactants (i.e. Triton X-100, Triton X-114 and PONPE 10) for preconcentration of phenothiazine derivatives before their determination by GC with flame ionization detector (FID). TX-114 provided the most efficient recovery of the phenothiazines tested. It was difficult to determine phenothiazine derivatives in the surfactant-rich phase by GC directly. Therefore, the separation of phenothiazine derivatives from surfactants can be accomplished by passing the surfactant rich phase through a cation exchange column. This surfactant clean-up procedure permits the determination of phenothiazine derivatives extracted in the surfactant-rich phase by GC-FID. The recoveries of pericyazine, chlorpromazine and fluphenazine from spiked serum samples were $95.1 \%$, $87.1 \%$ and $84.7 \%$, respectively.

Zhau et al., (2011) described a competitive method of CPE for the rapid and effective extraction and preconcentration of nine OPPs (Dichlorvos, methamidophos, acephate, diazinon, dimethoate, chlorpyrifos, parathion-methyl, malathion, parathion-ethyl) from concentrated fruit juice coupled with ultrasonic-assisted back-extraction prior to GC with flame photometric detection (GC-FPD) analysis. CPE coupled with ultrasonic-assisted backextraction has been combined with GC-FPD successfully. Under optimum conditions: a solution containing $6 \%\left(\mathrm{w} / \mathrm{v}\right.$ ) polyethylene glycol 6000 (PEG 6000) and 20\% (w/v) $\mathrm{Na}_{2} \mathrm{SO}_{4}$ for the extraction of the OPPs. The coacervation phase obtained was back extracted with ethyl acetate. The upper ethyl acetate solution was centrifugated simply for further cleanup for the sake of automatic injection. A preconcentration factor of 50 was obtained for these 9 pesticides. Using this method, the limits of detection (LOD) and limits of quantification (LOQ) were in the range of $0.5-3.0$ and $1.5-9.0 \mu \mathrm{g} \mathrm{kg-1}$ in concentrated fruit juice, respectively; the relative standard deviations (RSD) were less than $9 \%$.

An alternative approach for GC or GC/MS analysis of seven herbisides has been proposed by Takagai \& Hinze (2009). In this method, a post-extraction derivatization step is employed in which the surfactant in the surfactant-rich extractant phase is derivatized with $\mathrm{N}, \mathrm{O}-$ bis(trimethylsilyl) trifluoroacetamide (BSTFA) prior to introduction into the GC. Such derivatization step improved the chromatographic performance yielding a fairly wide 
elution time window absent of surfactant peaks, reproducible analyte retention times, and quantitative results. This approach enables the direct use of the surfactant-rich phase following CPE without any subsequent laborious column chromatographic or backextraction analyte isolation procedures. It should prove to be an attractive alternative approach for the GC or GC/MS analysis of analytes following their preconcentration by $\mathrm{CPE}$ in many situations.

In the recent times, OPPs were analyzed by Fontana et al. (2010) using a coacervative microextraction ultrasound-assisted back-extraction technique (CME-UABE) followed by GC-MS. The extraction/preconcentration technique is supported on the micellar organized medium based on non-ionic surfactant. To enable coupling the proposed technique with $\mathrm{GC}$, it was required to back extract the analytes into hexane. CME-UABE use alternative solvents such as surfactants and only require $60 \mu \mathrm{L}$ of hexane on the overall extraction procedure to achieve a satisfactory performance. The back-extracted analytes were introduced to GC-MS successfully without declining the separation efficiency of the capillary column. The recoveries were $\geq 90 \%$, indicating satisfactory robustness of the methodology, which could be successfully applied for determination of OPPs in honey samples of different Argentinean regions. Under optimal experimental conditions, the enrichment factor (EF) was 167.

To establish a GC method for simultaneous determination of organochlorine and pyrethroid pesticide residues in Viscum coloratum by CPE has been proposed by Zhang et al. (2009). Pesticides were extracted with the non-ionic surfactant TX-100. The apparatus was gas chromatography with electron capture detector and the separation was performed on an Hp-5 column. The pesticide residues were calculated by external standard method. The average recoveries of organochlorine and pyrethroid were $74.15 \%-111.6 \%$ with corresponding RSD of $4.0 \%-9.1 \%$.

\subsection{Capillary electrophoresis}

Capillary electrophoresis (CE), has increasingly gained importance in pesticide analysis (Balinova, 1996) and represents an attractive alternative for their determination. CPE has been applied as a preconcentration step prior to capillary electrophoresis (CE). The use of $\mathrm{CPE}$ as sample pretreatment techniques for pesticides prior to $\mathrm{CE}$ analysis has not been extensively investigated. The main problem of applying CPE to CE is that the surfactant-rich phase introduced into a bare fused-silica capillary using aqueous buffers would be adsorbed onto the wall of the capillary, leading to a marked loss of efficiency and reproducibility both in migration times and solute peak areas. To solve this problem, Carabias-Martínez et al. (1999b) used non-aqueous media in the separation buffer that can permit the electrophoretic separation of samples with high-surfactant contents, thus avoiding the adsorption of surfactant onto the wall of the capillary. The application of CPE to CE has been described and successfully applied for the determination of triazine herbicides in water samples (CarabiasMartínez et al., 1999; 2003). TX-114 was employed as the extraction solvent. The behaviour of a surfactant-rich micellar phase injected into a capillary electrophoresis system was studied using different separation modes. One problem that appeared on introducing a surfactant-rich phase into a bare fused-silica capillary, using aqueous buffers was that the surfactant was adsorbed onto the wall of the capillary, leading to a marked loss of efficiency and reproducibility. The use of dynamic coatings in the capillary, such as those obtained when the cationic surfactant $\mathrm{CTAB}$ is added to the separation buffer, afforded reproducible results, 
although half-life of the capillary was short (Xie et al., 2010). The most satisfactory results were obtained when the surfactant-rich samples were suitably diluted and injected, in the electrokinetic mode, into a non-aqueous separation medium of acetonitrile-methanol (50:50).

\section{Conclusion}

The present review has focused on the recent developments in CPE and its applications in conjunction with different analytical techniques. GC, HPLC, and CP have been used for the determination of different classes of pesticides by means of CPE. CPE was applied for preconcentration of organophosphorus, organochlorine and pyrethroid pesticides (Jia et al. , 2008; García-Pinto et al., 1995; Zhang et al., 2009; Fontana et al., 2010), carbamate pesticides (Zhou et al., 2009), triazole fungicides (Tang et al., 2010), benzimidazole fungicides (Halko et al., 2004), triazine herbicides (Carabias-Martínez et al., 1999), polychlorinated biphenyls (Fröschl et al., 1997). CPE using non-ionic surfactant such as POLE and Genapol X-080 provides good extraction efficiency of the studied fungicides, as compared to the conventional extraction method, such as solid-phase extraction (SPE). GC is very useful for the simultaneous determination of several pesticides at trace levels, and, in general, provides higher sensitivity rather than HPLC. But the use of CPE in combination with GC and also $\mathrm{CE}$ has appeared in few publications. The determination of pesticides has been carried out by GC coupled to sensitive and specific detection systems, such as the electron capture detector (ECD), flame photometry detector (FDP), flame ionization detector (FID) and MS detector. The performance of CPE in aqueous samples is excellent; however, it is not yet suitable in complex matrixes such as biological samples. Therefore, it needs further improvement.

\section{References}

Albanis, T. A.; Danis, T. G. \& Kourgia, M. K. (1994). Transportation of pesticides in estuaries of Axios, Loudias and Aliakmon rivers (Thermaikos Gulf). Science of the Total Environment, Vol.156, No.1, (November 1994), pp. 11-22, ISSN 0048-9697

Alvarez-Rodríguez, L.; Monferrer-Pons, L. I.; Esteve-Romero, J. S.; García-Alvarez-Coque, M. C. \& Ramis-Ramos, G. (1997). Spectrophotometric determination of carbamate pesticides with diazotized trimethylaniline in a micellar medium of sodium dodecyl sulfate. Analyst, Vol.122, No.5, (May 1997), pp. 459-463, ISSN 0003-2654

Anthemidis, A. N. \& Ioannou, K.-I. G. (2009). Recent developments in homogeneous and dispersive liquid-liquid extraction for inorganic elements determination. Talanta, Vol.80, No.2, (December 2009), pp. 413-421, ISSN 0039-9140

Antunes, P.; Gil, O. \& Bernardo-Gil, M. G. (2003). Supercritical fluid extraction of organochlorines from fish muscle with different sample preparation. Journal of Supercritical Fluids, Vol. 25, No. 2, (March 2003), pp. 135- 142, ISSN 0896-8446

Balinova, A. 1996. Strategies for chromatographic analysis of pesticide residues in water. Journal of Chromatography A, Vol. 754, No.1-2, (November 1996), pp. 125-35, ISSN 0021-9673

Balinova, A. M. \& Balinov, I. (1991). Determination of herbicides residues in soil in the presence of persistent organochlorine insecticides. Fresenius Journal Analytical Chemistry, Vol.339, No.6, (1991), pp. 409-412, ISSN1432-1130 
Barr, D. B. \& Needham L. L. (2002). Analytical methods for biological monitoring of exposure to pesticides. Journal of Chromatography B, Vol.778, No.1-2, (October 2002) pp. 5-29, ISSN 1570-0232

Bernal, J.; Nozal, M. J.; Jiménez, J. J.; Martín, M. T. \& Sanz, E. (2009). A new and simple method to determine trace levels of sulfonamides in honey by high performance liquid chromatography with fluorescence detection. Journal of Chromatography A, Vol.1216, No.43, (October 2009), pp. 7275-7280, ISSN 0021-9673

Blankschtein, D.; Thurston, G. M. \& Benedek, G. B. (1986). Phenomenological theory of equilibrium thermodynamic properties and phase separation of micellar solutions. Journal Chemical Physics, Vol.85, No.12, (December 1986), pp. 7268-7289, ISSN 00219606

Carabias-Martínez, R.; Rodriguez-Gonzalo, E.; Moreno-Cordero, B.; Perez- Pavon J. L.; Garcia-Pinto C. \& Laespada E. F. (2000). Surfactant cloud point extraction and preconcentration of organic compounds prior to chromatography and capillary electrophoresis. Journal of Chromatography A, Vol.902, No.1, (November 2000), pp. 251-265. ISSN 0021-9673

Carabias-Martínez, R., E.; Rodríguez-Gonzalo, E.; Domínguez-Álvarez, J.; García Pinto, C. \& Hernández-Méndez, J. (2003). Prediction of the behaviour of organic pollutants using cloud point extraction, Journal of Chromatography A, Vol.1005, No.1-2, (July 2003), pp. 23-34, ISSN 0021-9673

Carabias-Martínez, R.; Rodríguez-Gonzalo, E.; Domíngues-Álvarez, J. \& HernándezMéndez, J. (1999). Cloud point extraction as a preconcentration step prior to capillary electrophoresis. Analytical Chemistry, Vol.71, No.13, (May 1999), pp. 24682474, ISSN 0003-2700

Carabias-Martínez, R.; Rodríguez-Gonzalo, E.; García-Jiménez, M. G.; García-Pinto, C.; Pérez-Pavón, J. L. \& Hernández-Méndez, J. (1996). Determination of the fungicides folpet, captan and captafol by cloud-point preconcentration and high-performance liquid chromatography with electrochemical detection. Jounal chromatography A, Vol. 754, No.1-2, (November 1996), pp. 85-96, ISSN 0021-9673

Chang, S. \& Doong, R. (2006). Concentration and fate of persistent organochlorine pesticides in estuarine sediments using headspace solid-phase microextraction. Chemosphere, Vol. 62, No. 11, (March 2006), pp. 1869-1878, ISSN 0045-6535

Chen, J. B.; Liu, W.; Cui, Y. M.; Zhao, D. Y., \& Yang, M. M. (2008). Cloud point extraction for the determination of pesticides in strawberry juice by high performance liquid chromatographic detection. Chinese Journal of Analytical Chemistry, Vol.36, No.3, (March 2008), pp. 401-404, ISSN 1872-2040

Chen, J. B.; Zhao, W. J.; Liu W.; Zhou, Z. M. \& Yang, M. M. (2009). Cloud point extraction coupled with derivative of carbofuran as a preconcentration step prior to HPLC. Food Chemistry, Vol.115, No.3, (August 2009), pp.1038-1041, ISSN 0308-8146

Cho, Y.; Matsuoka, N. \& Kamiya, A. (1997). Determination of organophosphorus pesticides in biological samples of acute poisoning by HPLC with diode-array detector. Chemical Pharmaceutical Bulletin, Vol. 45, No. 4, (1997) , pp.737-740, ISSN 1347-5223

Claesson, P. M.; Kjellander, R.; Stenius P. \& Christenson, H. K. (1986). Direct measurement of temperature-dependent interactions between non-ionic surfactant layers. Journal of the Chemical Society, Faraday Transactions 1, Vol. 82, No.9, (September 1986), pp. 2735-2746, ISSN 0300-9599 
Coly, A. \& Aaron, J.-J. (1998). Fluorimetric analysis of pesticides: Methods, recent developments and applications. Talanta, Vol.46, No.5, (August 1998), pp. 815-843, ISSN 0039-9140

Corti, M.; DeGiorgio, V.; Hayter, J. B. \& Zulanf, M. (1984). Micelle structure in isotropic $\mathrm{C}_{12} \mathrm{E}_{8}$ amphiphile solutions. Chemical Physical Letter, Vol.109, No.6, (September 1984), pp. 579-583, ISSN 0009-2614

de Almeida Bezerra, M.; Arruda, M. A. Z. \& Ferreira, S. L. C. (2005). Cloud point extraction as a procedure of separation and pre-concentration for metal determination using spectroanalytical techniques. Applied Spectroscopy Reviews, Vol. 40 (July 2005), pp. 269-299, ISSN 0570-4928

DeGiorgio, V.; Piazza, R.; Corti, M. \& Minero C. (1984). Critical properties of nonionic micellar solutions, Journal Chemical Physics, Vol.82, No.2, (January 1984), pp. 10251032, ISSN 0021-9606

DiCorcia, A. \& Marchetti, M. (1991). Multiresidue method for pesticides in drinking water using a graphitized carbon black cartridge extraction and liquid chromatographic analysis, Analytical Chemistry, Vol.63, No.6, (March 1991), pp. 580-585, ISSN 00032700

Ding, Y.; Qin, W.\& Dai, Y. (2009). Determination of organophosphate pesticide residues by cloud point extraction. Qinghua Daxue Xuebao/Journal of Tsinghua University, Vol. 49 No. 3, (2009), pp. 407-410, ISSN 1000-0054

Dyson, J. S.; Beulke, S.; Brown C. D. \& Lane, M. C. G. (2002). Adsorption and degradation of the weak acid mesotrione in soil and environmental fate implications. Journal of Environmental Quality, Vol. 31, No. 2, (2002), pp. 613-618, ISSN 0047-2425

Eiguren-Fernández, A.; Sosa-Ferrera, Z. \& Santana-Rodríguez, J. J. (1998). Determination of polychlorinated biphenyls by liquid chromatography following cloud-point extraction. Analytica Chimica Acta, Vol. 358, No. 2, (January 1998), pp. 145-155, ISSN 0003-2670

Eiguren-Fernández, A.; Sosa-Ferrera, Z. \& Santana-Rodríguez, J. J. (1999). Application of cloud-point methodology to the determination of polychlorinated dibenzofurans in sea water by high-performance liquid chromatography. Analyst, Vol.124, No. 4 (1999), pp. 487-491, ISSN 0003-2654

Ellington, J. J.; Evans, J. J.; Prickett, K. B. \& Champion, W. L. (2001). High-performance liquid chromatographic separation of the enantiomers of organophosphorus pesticides on polysaccharide chiral stationary phases. Journal Chromatography A, Vol.928, No. 2, (August 2001), pp. 145-154, ISSN 0021-9673

Eskilsson, C. S. \& Mathiasson, L. (2000). Supercritical fluid extraction of the pesticides carbosulfan and imidacloprid from Process Dust Waste. Journal of Agricultural $\mathcal{E}$ Food Chemistry, Vol. 48, No. 11, (November 2000), pp. 5159-5164, ISSN 0021-8561

Evdokimov, E. \& von Wandruszka, R. (1998). Decontamination of DDT-polluted soil by Soil Washing/cloud point extraction. Analytical Letters, Vol. 31, No.13, (1998), pp. 22892298, ISSN1532-236X

Fang, J. G.; Lv, C. G.; Zhu, W. T.; Qiu, J.; Wang, X. Q. \& Zhou, Z. Q. (2008). Applicability of cloud point extraction coupled with microwave-assisted back-extraction to the determination of organophosphorous pesticides in human urine by gas chromatography with flame photometry detection. Journal of Hazardous Materials, Vol. 159, No. 2-3, (November 2008), pp. 300-305, ISSN 0304- 3894 
Faria, A. M.; Dardengo, R. P.; Lima, C. F.; Neves, A. A. \& Queiroz, M. E. L. R. (2007). Determination of disulfoton in surface water samples by cloud-point extraction and gas chromatography. International Journal of Environmental \& Analytical Chemistry, Vol. 87, No. 4, (April 2007) pp. 249-258, ISSN 0306-7319

Fernández, A. E.; Ferrera, Z. S. \& Rodriguez, J. J. S. (1999). Application of cloud-point methodology to the determination of polychlorinated dibenzofurans in sea water by high-performance liquid chromatography. Analyst, Vol. 124, No.4, (1999), pp. 487-491, ISSN 0003-2654

Fernández-Alba, A. R. (2005). Ed. Chromatographic-Mass Spectrometric Food Analysis for Trace Determination of Pesticide Residues; Elsevier: Amsterdam, The Netherlands, 2005

Ferrer, R.; Beltran, J. L. \& Guiteras, J. (1996). Use of cloud point extraction methodology for the determination of PAHs priority pollutants in water samples by highperformance liquid chromatography with fluorescence detection and wavelength programming, Analytica Chimica Acta, Vol. 330, No.2-3, (September 1996), pp. 199206, ISSN 0003-2670.

Ferrera, Z. S.; Sanz, C. P.; Santana, C. M. \& Rodríguez, J. J. S. (2004). The use of micellar systems in the extraction and pre-concentration of organic pollutants in environmental samples, TrAC Trends Analytical Chemistry, Vol. 23, No. 7, (August 2004), pp. 469-479, ISSN 0165-9936

Fontana, A. R.; Camargo, A. B. \& Altamirano J. C.(2010). Coacervative microextraction ultrasound-assisted back-extraction technique for determination of organophosphates pesticides in honey samples by gas chromatography-mass spectrometry. Journal of Chromatography A, Vol.1217, No.41, (October 2010), 63346341, ISSN 0021-9673

Fröschl, B.; Stangl, G. \& Niessner, R. (1997). Combination of micellar extraction and GCECD for the determination of polychlorinated biphenyls (PCBs) inwater. Fresenius' Journal of Analytical Chemistry, Vol. 357, No. 6, (July 1997), pp. 743-746, ISSN 09370633

García-Pinto, C.; Pérez-Pavón J. L. \& Moreno-Cordero, B. (1995). Cloud point preconcentration and high performance liquid chromatographic determination of organophosphorus pesticides with Dual Electrochemical Detection. Analytical Chemistry, Vol. 67, No. 15, (August 1995), pp. 2606-2696, ISSN 0003-2700

García-Reyes, J. F.; Gilbert-López, B. \& Molina-Díaz, A. (2008). Determination of pesticide residues in Fruit-Based Soft Drinks. Analytical Chemistry, Vol. 80, No. 23, (December 2008), pp. 8966-8974, ISSN 0003-2700

Giokas, D. L.; Sakkas, V. A.; Albanis, T. A. \& Lampropoulou, D. A. (2005). Determination of Uv filter residues in bathing waters by liquid chromatography UV-diode array and gas chromatography-mass spectrometry after micelle mediated extraction solvent back extraction. Journal of Chromatography A, Vol. 1077, No. 1, (June 2005), pp. 19-27, ISSN 0021-9673

Guzzella, L.; Pozzoni, F. \& Giuliano, G. (2006). Herbicide contamination of surficial groundwater in Northern Italy. Environmental Pollution, Vol. 142, No.2, (July 2006), pp. 344-353, ISSN 0269-7491

Halko, R. \& Hutta, M. (2002). Study of high-performance liquid chromatographic separation of selected herbicides by hydro-methanolic and micellar liquid chromatography 
using Genapol X-080 non-ionic surfactant as mobile phase constituent. Analytica Chimica Acta, Vol, 466, No.2, (August 2002), pp.325-333, ISSN 0003-2670

Halko, R.; Sanz, C. P.; Ferrera, Z. S. \& Rodríguez, J. J. S. (2004). Determination of Benzimidazole Fungicides by HPLC with Fluorescence Detection After Micellar Extraction. Chromatographia,Vol. 60, (July 2004), pp.151-156, ISSN 0009-5893

Hamilton, D. J.; Ambrus, A.; Dieterle, M.; Felsot, A. S.; Harris, C. A.; Holland, P. T.; Katayama, A.; Kurihara, N.; Linders, J.; Unsworth, J. \& Wong, S.-S. (2003). Regulatory limits for pesticide residues in water (IUPAC Technical Report). Pure $\mathcal{E}$ Applied Chemistry, Vol. 75, No. 8, (2003), pp. 1123-1155, ISSN 0033-4545

Harner, T.; Bartkow, M.; Holoubek, I.; Klanova, J.; Wania, F.; Gioia, R.; Moeckel, C.; Sweetman, A. J. \& Jones, K. C. (2006). Passive air sampling for persistent organic pollutants: introductory remarks to the special issue. Environmental Pollution, Vol. 144, No. 2, (November 2006), pp. 361-340, ISSN 0269-7491

Hassal, K. A. (1983). The Chemistry of Pesticides: Their Methabolism, Mode of Action and Uses in Crop Protection; MacMillan: New York, 1983; pp .264-285.

Hinze, W. L.; Singh, H. N.; Baba, Y. \& Harvey, N. G. (1984). Micellar enhanced analytical fluorimetry. TrAC Trends Analytical Chemistry, Vol.3, No.8, (1984), pp.193-199, ISSN 0165-9936

Hopper, M. L. (1999). Automated one-step supercritical fluid extraction and clean-up system for the analysis of pesticide residues in fatty matrices, Journal of Chromatography A, Vol.840, No.1, (April 1999), pp. 93-105, ISSN 0021-9673

Howard, A. L. \& Taylor, L. T. (1993). Considerations for analytical supercritical fluid extraction of sulfonyl ureas employing a modified fluid. Journal of High Resolution Chromatography, Vol. 16, No. 1, (January 1993), pp. 39-45, ISSN 0344-7138

Howard, A. L.; Braue, C. \& Taylor, L. T. (1993). Feasibility of thiocarbamate pesticide analysis in apples by supercritical fluid extraction and high-performance liquid chromatography. Journal of Chromatographic Science, Vol. 31, No.7, (August 1993), pp. 323-329, ISSN 0021-9665

http://ec.europa.eu/environment/water/water-drink/revision_en.html.

Izquierdo, A.; Tena, M. T.; Luque de Castro, M. D. \& Valcarcel, M. (1996). Supercritical fluid extraction of carbamate pesticides from soils and cereals. Chromatographia, Vol. 42, No. 3-4, (February 1996), pp. 206-212, ISSN 0009-5893

Jia, G. F.; Lv, C. G.; Zhu, W. T.; Qiu, J.; Wang, X. Q. \& Zhou Z. Q. (2008). Applicability of cloud point extraction coupled with microwave-assisted back-extraction to the determination of organophosphorous pesticides in human urine by gas chromatography with flame photometry detection. Journal of Hazardous Materials, Vol. 159, No.2-3, (November 2008), pp. 300-305, ISSN 0304-389

Jia, G.; Bi, C.; Wang, Q.; Qiu, J.; Zhou, W. \& Zhou, Z. (2006). Determination of Etofenprox in environmental samples by HPLC after anionic surfactant micelle-mediated extraction (coacervation extraction). Analytical \& Bioanalalytical Chemistry, Vol. 384, No. 6, (March 2006), pp. 1423-1427, ISSN 1618-2642

Khalaf, K. D.; Morales-Rubio, A. \& Guardia, M. (1993). Simple and rapid Flow-injection spectrophotometric determination of carbaryl after liquid-liquid extraction. Analytica Chimica Acta, Vol. 280, No. 1, (August 1993), pp. 231-238, ISSN 0003-2670 
Kjellander, R. \& Florin, E. (1981). Water structure and changes in thermal stability of the system poly(ethylene oxide)-water. Journal of the Chemical Society, Faraday Transactions 1, Vol. 177, No. 9. ( September 1981), pp. 2053-2077, ISSN 0300-9599

Komaromy-Hiller, G., Calkins, N. \& Wandruszka, R. (1996). Changes in polarity and aggregation number upon clouding of a nonionic detergent: effect of ionic surfactants and sodium chloride. Langmuir, Vol. 12, No. 4, (February 1996), pp. $916-$ 920, 0743-7463

Konstantinou, I. K.; Hela, D. G. \& Albanis, T. A. (2006). The status of pesticide pollution in surface waters (rivers and lakes) of Greece. Part I. Review on occurrence and levels. Environmental Pollution, Vol. 141, No. 3, (June 2006), pp. 555-570, ISSN 0269-7491

Kukusamude, C.; Santalad, A.; Boonchiangma, S.; Burakham, R.; Srijaranai, S. \& Chailapakul, O. (2010). Mixed micelle-cloud point extraction for the analysis of penicillin residues in bovine milk by high performance liquid chromatography. Talanta, Vol. 81, No.1-2, (April 2010), pp. 486-492, ISSN 0039-9140

Lambropoulou, D. A.\& Albanis T. A. (2007). Liquid-phase micro-extraction techniques in pesticide residue analysis. Journal of Biochemical \& Biophysical Methods, Vol.70, No. 2 (March 2007), pp. 195-228, ISSN 0165-022X

Lehotay, S. J. (1997). Supercritical fluid extraction. Journal of Chromatography A, Vol. 785, No. 1-2, (October 1997), pp. 289-312, ISSN 0021-9673

Lindman, B. \& Wennerstrom, H. (1991). Nonionic micelles grow with increasing temperature. Journal of Physical Chemistry, Vol.95, No.15, (July 1991), pp. 6053-6054, ISSN 1520-5207

Ling, Y.-C.; Teng, H.-C. \& Cartwright, C. (1999). Supercritical fluid extraction and clean-up of organochlorine pesticides in Chinese herbal medicine. Journal of Chromatography A, Vol. 835, No. 1-2, (March 1999), pp. 145-157, ISSN 0021-9673

Liu, C. -L.; Nikas, Y. J. \& Blankschtein, D. (1996). Novel bioseparations using two phase aqueous micellar systems, Biotechnol. Bioeng. Vol.52, No.2, (October 1996), pp. 185192, ISSN 1097-0290

Liu, J. F.; Chao, J. B.; Jiang, G. B.; Cai, Y.Q. \& Liu, J. M. (2003). Trace analysis of sulfonylurea herbicides in water by on-line continuous flow liquid membrane extractionC18 precolumn liquid chromatography with ultraviolet absorbance detection. Jounal Chromatography A, Vol. 995, No. 1-2, (May 2003), pp. 21-28, ISSN 0021-9673

López-Pérez, G. C.; Arias-Estévez, M.; López-Periago, E.; Soto-González, B.; Cancho-Grande, B. \& Simal-Gándara, J. (2006). Dynamics of pesticides in potato crops. Journal of Agricultural \& Food Chemistry, Vol. 54, No. 5, (March 2006), pp. 1797-1803, ISSN 0021-8561

Luque de Castro, M. D. \& García-Ayuso, L. E. (1998). Soxhlet extraction of solid materials: an outdated technique with a promising innovative future. Analytica Chimica Acta, Vol. 369, No. 1-2, (August 1998), pp.1-10, ISSN 0003-2670

Luque de Castro, M. D. \& Jimènez-Carmona, M. M. (1998). Potential of water for continuous automated sample-leaching. TrAc Trends in Analytical Chemistry, Vol. 17, No. 7, (August 1998), pp. 441-447, ISSN 0165- 9936

Madej K. (2009). Microwave-assisted and cloud-point extraction in determination of drugsand other bioactive compounds. TrAC Trends in Analytical Chemistry, Vol. 28, No. 4, (April 2009 ), pp. 436-445, ISSN 0165-9936 
McIntire, G. L.(1990). Micelles in Analytical Chemistry. Critical Reviws. in Analytical Chemistry, Vol. 21, No. 4, (1990), pp. 257-278, ISSN 1040-8347

Melchert, W. R. \& Rocha, F. R. P. (2009). Cloud point extraction and concentration of carbaryl from natural waters, International Journal of Environmental Analytical Chemistry, Vol. 89, No. 13, (November 2009), pp. 969-979, ISSN 0306-7319

Miro, M.; Estela, J. M. \& Cerda, V. (2005). Recent Advances in On-line Solvent Extraction Exploiting Flow Injection/Sequential Injection Analysis. Current Analytical Chemistry, Vol.1, No.3, (November 2005), pp. 329-344, ISSN 1573-4110

Moreno, D. V.; Ferrera, Z. S. \& Rodríguez, J. J. S. (2006). Use of polyoxyethylene surfactants for the extraction of organochlorine pesticides from agricultural soils. Journal of Chromatography A, Vol. 1104, No.1-2, (February 2006) , pp. 11-17, ISSN 0021-9673

Moreno-Cordero, B.; Perez Pavon, J. L.; Garcia Pinto, C. \& Fernandez Laespada, M. E. (1993). Cloud point methodology: A new approach for preconcentration and separation in hydrodynamic systems of analysis. Talanta, Vol. 40, No. 11, (November 1993), pp. 1703-1710, ISSN 0039-9140

Moreno-Cordero, B.; Pérez-Pavón, J. L. \& García-Pinto, C. (1998). in: R.A. Meyer (Ed.), Encyclopedia of Environmental Analysis and Remediation, Wiley, 1998

Núñez, O.; Moyano, E. \& Galceran, M. T. (2005). LC-MS/MS analysis of organic toxics in food. TrAC Trends in Analytical Chemistry, Vol. 24, No.7, (July-August 2005), pp. 683-703, ISSN 0165-9936

Ohashi, A.; Ogiwara, M.; Ikeda, R.; Okada H. \& Ohashi, K. (2004). Cloud point extraction and preconcentration gas chromatography of phenothiazines tranquilizers in spiked human serum. Analytical Sciences, Vol. 20, No. 9, (2004), pp. 1353-1357, ISSN 0910-6340

Okada, T. (1992). Temperature Induced Phase Separation of Nonionic Polyoxyethylated Surfactant and Application to Extraction of Metal Thiocyanates, Analytical Chemistry, Vol. 64, No. 18, (September 1992), pp. 2138-2142, ISSN 0003-2700

Paleologos, E. K.; Giannakopoulos, S. S.; Zygoura, P. D. \& Kontominas, M. G. (2006). AcidInduced Phase Separation of Anionic Surfactants for the Extraction of 1,4Dichlorobenzene from Honey Prior to Liquid Chromatography. Journal of Agricultural \& Food Chemistry, Vol. 54, No.15, (June 2006), pp. 5236-5240, ISSN 00218561

Paleologos, E. K., Giokas, D. L. \& Karayannis, M. I. (2005). Micelle-mediated separation and cloud-point extraction. Trends in Analytical Chemistry, Vol. 24, No. 5, (May 2005), pp. 426-436, ISSN 0021-8561

Papadopoulou-Mourkidou, E.; Karpouzas, D. G.; Patsias, J.; Kotopoulou, A.; Milothridou, A.; Kintzikoglou, K. \& Vlachou, P. (2004). The potential of pesticides to contaminate the groundwater resources of the Axios river basin in Macedonia Northern Greece. Part I. Monitoring study in the north part of the basin. Science of the Total Environment, Vol. 321, No.1-3, (April 2004), pp.127-146, ISSN 0048-9697

Pena-Pereira, F.; Lavilla, I. \& Bendicho, C. (2009). Miniaturized preconcentration methods based on liquid-liquid extraction and their application in inorganic ultratrace analysis and speciation. Spectrochimica Acta, Part B, Vol. 64, No.1, (January 2009), pp. 1-15, ISSN 0584-8547 
Pico', Y.; Rodríguez, R. \& Mañes, J. (2003). Capillary electrophoresis for the determination of pesticide residues. TrAC Trends in Analytical Chemistry, Vol. 22, No. 3, ( March 2003), pp. 133-151, ISSN 0165-9936

Pinto, C. G.; Pavon, J. L. P. \& Cordero, B. M. (1992). Cloud Point Preconcentration and High-Performance Liquid Chromatographic Analysis with Electrochemical Detection. Analytical Chemistry, Vol. 64, No. 20, (October 1992), pp. 2334-2338, ISSN 0003-2700

Pinto, C. G.; Pavón, J. L. W. \& Cordero, B. M. (1995). Cloud Point Preconcentration and High Performance Liquid Chromatographic Determination of Organophosphorus Pesticides with Dual Electrochemical Detection, Analytical Chemistry, Vol. 67, No. 15, (August 1995), pp. 2606-2612, ISSN 0003-2700

Pramauro, E. \& Prevot, A. B. (1995). Solubilization in micellar systems. Analytical and environmental applications, Pure Applied Chemistry, Vol. 67, No. 4, (August 1995), pp. 551-559, ISSN 1365-3075

Quina, F. H. \& Hinze, W. L. (1999). Surfactant-Mediated Cloud Point Extractions: An Environmentally Benign Alternative Separation Approach. Industrial \& Engineering Chemistry Research, Vol. 38, No. 11, (September 1999) 4150-4168, ISSN 0888-5885

Reighard, T. S. \& Olesik, S. V. (1997). Extraction of phenoxyacid herbicides from house dust using methanol/ $\mathrm{CO}_{2}$ mixtures, Analytical Chemistry, Vol. 69, No. 4, (February 1997), pp. 566-574, ISSN 0003-2700

Rezaee, M.; Yamini, Y. \& Faraji, M. (2010). Evolution of dispersive liquid-liquid microextraction method. Journal of Chromatography A, Vol. 1217, No.16, (April 2010), pp. 2342-2357, ISSN 0021-9673

Roseboom, H. \& Herbold H. A. (1980). Chromatographic methods for determination of pesticide residues. Journal of Chromatography A, Vol. 202, No. 3, (December 1980), pp. 431-438, ISSN 0021-9673

Saitoh, T. \& Hinze, W. L. (1991). Concentration of Hydrophobic Organic Compounds and Extraction of Protein Using Alkylammoniosulfate Zwitterionic Surfactant Mediated Phase Separations (Cloud Point Extractions). Analytical Chemistry, Vol. 63, No. 21, (November 1991), pp. 2520-2525, ISSN 0003-2700

Saitoh, T.; Matsudo T. \& Matsubara, C. (2000). Micelle-mediated extraction for concentrating hydrophobic organic compounds. Journal of Chromatography A, Vol. 879, No. 2, (May 2000), pp. 121-128, ISSN 0021-9673

Santalad, A; Srijaranai, S.; Burakham, R.; Sakai, T. \& Deming, R. L. (2008). Acid-induced cloud-point extraction coupled to spectrophotometry for the determination of carbaryl residues in waters and vegetables. Microchemical Journal, Vol. 90, No.1, (October 2008), pp. 50-55, ISSN 0026-265X

Sanz, C. P.; Halko, R.; Ferrera, Z. S. \& Rodríguez, J. J. S. (2004). Micellar extraction of organophosphorus pesticides and their determination by liquid chromatography. Analytica Chimica Acta, Vol. 524, No. 1-2, (October 2004), pp. 265-270, ISSN 00032670

Shariati, S. \& Yamini, Y. (2006). Cloud point extraction and simultaneous determination of zirconium and hafnium using ICP-OES. Journal of Colloid \& Interface Science, Vol. 298, No. 1, (June 2006), pp. 419-425, ISSN 0021-9797 
Shen, J. \& Shao, X. (2006). Determination of tobacco alkaloids by gas chromatography-mass spectrometry using cloud point extraction as a preconcentration step. Analytica Chimica Acta, Vol. 561, No. 1-2, (March 2006), pp. 83-87, ISSN 0003-2670

Sikalos, T. I. \& Paleologos, E. K. (2005). Cloud point extraction coupled with microwave or ultrasonic assisted back extraction as a preconcentration step prior to gas chromatography. Analytical Chemistry, Vol. 77, No. 8, (March 2005), pp. 2544-2549, ISSN 0003-2700

Silva, M. F.; Cerutti, E. S. \& Martinez L. D. (2006). Coupling Cloud Point Extraction to Instrumental Detection Systems for Metal Analysis. Microchimica Acta, Vol. 155, No.3-4, (October 2006), pp. 349-364, ISSN 0026-3672

Simonian, A. L.; Rainina, E. I. \& Wild J. R. (1997). A new approach for discriminative detection of organophosphate neurotoxins in the presence of other cholinesterase inhibitors, Analytical Letters, Vol. 30, No. 14, (1997), pp. 2453-2468, ISSN 1532-236X.

Snyder, J. L.; Grob, R. L.; McNally, M. E. \& Oostdyk, T. S. (1993). The effect of instrumental parameters and soil matrix on recovery of organochlorine and organophosphate pesticides from soils using supercritical fluid extraction, Journal of Chromatographic Science, Vol. 31, No, 5, (May 1993), pp. 183-191, ISSN 0021-9665

Stalikas, C. D. (2002). Micelle-mediated extraction as a tool for separation and preconcentration in metal analysis. TrAC Trends in Analytical Chemistry, V. 21, No. 5, (May 2002), pp. 343-355, ISSN 0021-8561

Stangl, G. \& Niessner, R. Cloud point extraction of napropamide and thiabendazole from water and soil. Microchimica Acta, Vol. 113, No. 1-2, (1994), pp.1-8, ISSN 0026-3672

Stangl, G.; Niessner, R. \& Albaiges, J. (1995). Micellar extraction- a new step for enrichment in the analysis of napropamide, International Journal of Environmental \& Analytical Chemistry, Vol. 58, No.1-4, (January 1995), pp. 15-22, ISSN 0306-7319

Swann, R. L.; Laskowski, D.A.; McCall, P.J.; Kuy, K.V. \& Dishburger, H. J. (1983). A rapid method for the estimation of the environmental parameters octanol/water partition coefficient, soil sorption constant, water to air ratio, and water solubility, Residue Reviews, 85 (1983), pp. 17-27, ISSN 0080-181X

Tadeo, J. L.; Sánchez-Brunete, C.; Albero, B. \& García-Valcárcel, A. I. (2010). Application of ultrasound-assisted extraction to the determination of contaminants in food and soil samples. Journal of Chromatography A, Vol. 1217, No. 16, (April 2010), pp. 24152440, ISSN 0021-9673

Takagai, Y. \& Hinze, W. L. (2009). Cloud Point Extraction with Surfactant Derivatization as an Enrichment Step Prior to Gas Chromatographic or Gas Chromatography-Mass Spectrometric Analysis. Analytical Chemistry, Vol. 81, No. 16, (July 2009), pp. 71137122, ISSN 0003-2700

Tang, T.; Qian, K.; Shi, T.; Wang, F.; Li, J. \& Cao, Y. (2010). Determination of triazole fungicides in environmental water samples by high performance liquid chromatography with cloud point extraction using polyethylene glycol 600 monooleate, Analytica Chimica Acta, Vol. 680, No. 1-2, (November 2010), pp. 26-31, ISSN 0003-2670

Voorhees, K. J.; Gharaibeh, A. A. \& Murugaverl, B. (1998). Integrated SFE/SFC/MS system for the analysis of pesticides in animal tissue. Journal of Agricultural and Food Chemistry, Vol. 46, No. 6, (July 1998), pp. 2353-2359, ISSN 0021-8561 
Wang, J.; Cui, Y.; Liu, W.; Yang, M.\& Chen, J. (2007). Determination of six pesticides in milk using cloud point extraction-high performance liquid chromatography, Chinese Journal of Chromatography (Se Pu), Vol. 25, No. 6, (2007), pp. 853-856, ISSN 0253-3820

Watanabe, H. \& Tanaka, H. (1978). A non-ionic surfactant as a new solvent for liquidliquid extraction of zinc(II) with 1-(2-pyridylazo)-2-naphthol. Talanta, Vol. 25, No. 10, (October 1978), pp. 585-589, ISSN 0039-9140

Wu, Y. J.; Fu, X. W. \& Yang, H. (2010). Cloud Point Extraction With Triton X-114 for Separation of Metsulfuron-Methyl, Chlorsulfuron, and Bensulfuron-Methyl From Water, Soil, and Rice and Analysis by High-Performance Liquid Chromatography. Archives of Environmental Contamination and Toxicology, (December 2010), DOI 10.1007/s00244-010-9626-y, ISSN 0090-4341

Xie, S.; Paau, M. C.; Li, C. F.; Xiao, D. \& Choi, M. M. F. (2010). Separation and preconcentration of persistent organic pollutants by cloud point extraction. Journal of Chromatography A, Vol. 1217, No. 16, (April 2009), pp. 2306-2317, ISSN 0021-9673.

$\mathrm{Xu}$, L.; Basheer, C. \& Lee, H. K. (2007). Developments in single-drop microextraction. Journal of Chromatography A, Vol. 1152, No.1-2, (June 2007), pp. 184-192, ISSN 00219673

Yeboah, P. O. (2001). Trends and advances in pesticides residue analysis. Journal of Applied Science and Technology, Vol. 6, No. 1-2 (2001), pp. 101-107, ISSN-0855-2215

Zanella, R.; Dallago, R.; Flores, E. M. M. \& Martins A. F. (1999). Flow injection spectrophotometric determination of carbofuran in commercial pesticides formulations. Analytical Letters, Vol. 32, No. 3, (1999), pp. 593-600, ISSN 1532-236X

Zhang, S.; Chen, X.; Yu, Z.; Shen, X.; Gou, M.\& Bi, K. (2009). Determination of twenty pesticide residues in Viscum coloratum by gas chromatography using cloud-point extraction. Zhongguo Zhongyao Zazhi, Vol. 34, No. 20, (2009), pp. 2577-2580, ISSN 1001-5302

Zhang, W.; Duan, C. \& Wang, M. (2011) Analysis of seven sulphonamides in milk by cloud point extraction and high performance liquid chromatography, Food Chemistry, Vol. 126, No. 2, (May 2011), pp. 779-785, ISSN 0308-8146

Zhao, W-j.; Sun, X-k.; Deng, X-n.; Huang, L.; Yang, M-m. \& Zhou, Z-m. (2011). Cloud Point Extraction Coupled with Ultrasonic-assisted Back-extraction to Determination of Organophosphorus Pesticides in Concentrated fruit juice by Gas Chromatography with Flame Photometric Detection, Food Chemistry, (2011), doi: 10.1016/j.foodchem.2010.12.122

Zhou, J.; Chen, J.; Cheng, Y.; Li, D.; Hu, F. \& Li, H. (2009a). Determination of Prometryne in water and soil by HPLC-UV using cloud-point extraction. Talanta, Vol. 79, No. 2, (July 2009), pp. 189-193, ISSN 0039-9140

Zhou, Z.-M.; Chen, J. -B.; Zhao, D.-Y. \& Yang M.-M. (2009b). Determination of Four Carbamate Pesticides in Corn by Cloud Point Extraction and High-Performance Liquid Chromatography in the Visible Region Based on Their Derivatization Reaction. Journal Agricultural Food Chemistry, Vol. 57, No.19, (October 2009), pp. 8722-8727, ISSN 0021-8561

Zhu, H.-zhen; Liu, W.; Mao, J.-wei \& Yang M.-min. (2007). Cloud point extraction and determination of trace trichlorfon by high performance liquid chromatography with ultraviolet-detection based on its catalytic effect on benzidine oxidizing. Analytica Chimica Acta, Vol. 614, No. 1, ( April 2008 ), pp.58-62, ISSN 0003-2670 
Zygoura, P. D.; Paleologos, E. K.; Riganakos, K. A. \& Kontominas, M. G. (2005). Determination of diethylhexyladipate and acetyltributylcitrate in aqueous extracts after cloud point extraction coupled with microwave assisted back extraction and gas chromatographic separation. Journal of Chromatography A, Vol. 1093, No. 1-2, (November 2005), pp. 29-35, ISSN 0021-9673 


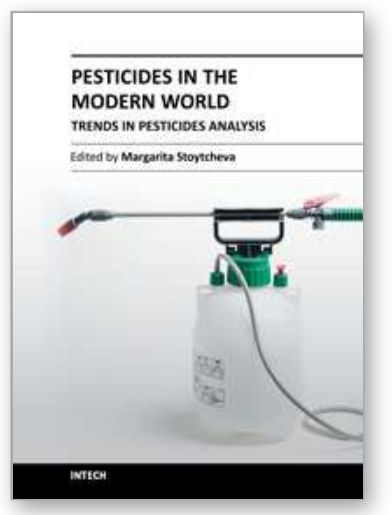

\author{
Pesticides in the Modern World - Trends in Pesticides Analysis \\ Edited by Dr. Margarita Stoytcheva
}

ISBN 978-953-307-437-5

Hard cover, 514 pages

Publisher InTech

Published online 21, October, 2011

Published in print edition October, 2011

The book offers a professional look on the recent achievements and emerging trends in pesticides analysis, including pesticides identification and characterization. The 20 chapters are organized in three sections. The first book section addresses issues associated with pesticides classification, pesticides properties and environmental risks, and pesticides safe management, and provides a general overview on the advanced chromatographic and sensors- and biosensors-based methods for pesticides determination. The second book section is specially devoted to the chromatographic pesticides quantification, including sample preparation. The basic principles of the modern extraction techniques, such as: accelerated solvent extraction, supercritical fluid extraction, microwave assisted extraction, solid phase extraction, solid phase microextraction, matrix solid phase dispersion extraction, cloud point extraction, and QuEChERS are comprehensively described and critically evaluated. The third book section describes some alternative analytical approaches to the conventional methods of pesticides determination. These include voltammetric techniques making use of electrochemical sensors and biosensors, and solid-phase spectrometry combined with flow-injection analysis applying flow-based optosensors.

\title{
How to reference
}

In order to correctly reference this scholarly work, feel free to copy and paste the following:

Hayati Filik and Sema Demirci Çekiç (2011). Cloud Point Extraction of Pesticide Residues, Pesticides in the Modern World - Trends in Pesticides Analysis, Dr. Margarita Stoytcheva (Ed.), ISBN: 978-953-307-437-5, InTech, Available from: http://www.intechopen.com/books/pesticides-in-the-modern-world-trends-in-pesticidesanalysis/cloud-point-extraction-of-pesticide-residues

\section{INTECH}

open science / open minds

\section{InTech Europe}

University Campus STeP Ri

Slavka Krautzeka 83/A

51000 Rijeka, Croatia

Phone: +385 (51) 770447

Fax: +385 (51) 686166

www.intechopen.com

\section{InTech China}

Unit 405, Office Block, Hotel Equatorial Shanghai

No.65, Yan An Road (West), Shanghai, 200040, China

中国上海市延安西路 65 号上海国际贵都大饭店办公楼 405 单元

Phone: +86-21-62489820

Fax: +86-21-62489821 
(C) 2011 The Author(s). Licensee IntechOpen. This is an open access article distributed under the terms of the Creative Commons Attribution 3.0 License, which permits unrestricted use, distribution, and reproduction in any medium, provided the original work is properly cited. 